\title{
Increasing the $\mathrm{CO}_{2}$ Reduction Activity of Cobalt
}

\section{Phthalocyanine by Modulating the $\sigma$-donor Strength of Axially}

\section{Coordinating Ligands}

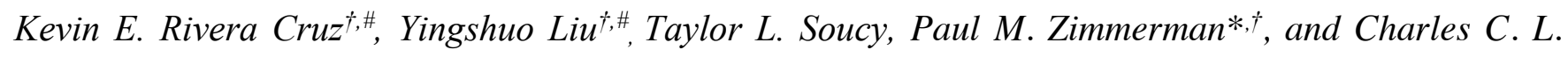
McCrory* $\%$,s

Department of Chemistry, University of Michigan, Ann Arbor, Michigan, 48109-1055, United States.

${ }^{\S}$ Macromolecular Science and Engineering Program, University of Michigan, Ann Arbor, Michigan, 48109-1055, United States.

${ }^{\#}$ K.E.R.C. and Y.L. contributed equally.

\section{ABSTRACT}

Axial coordination of a pyridyl moieties to CoPc (either exogenous or within poly-4-vinylpyridine polymer) dramatically increases the complex's activity for $\mathrm{CO}_{2} \mathrm{RR}$. It has been hypothesized that axial coordination to the Co active site leads to an increase in the Co $\mathrm{dz}^{2}$ orbital energy, which increases the complex's nucleophilicity and facilitates $\mathrm{CO}_{2}$ coordination compared to the parent $\mathrm{CoPc}$ complex. The

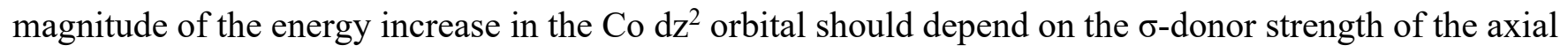
ligand - a stronger $\sigma$-donating ligand $(\mathrm{L})$ will increase the overall $\mathrm{CO}_{2} \mathrm{RR}$ activity of axially coordinated $\operatorname{CoPc}(\mathrm{L})$ and vice versa. To test this, we have studied a series of $\operatorname{CoPc}(\mathrm{L})$ complexes where the $\sigma$-donor strength of $\mathrm{L}$ is varied. We show that $\mathrm{CoPc}(\mathrm{L})$ reduces $\mathrm{CO}_{2}$ with an increased activity as the $\sigma$-donor ability of L is increased. These observed electrochemical activity trends are correlated with 
computationally-derived $\mathrm{CO}_{2}$ binding energy and charge transfer terms as a function of $\sigma$-donor strength. The findings of this study supports our hypothesis that the increased $\mathrm{CO}_{2} \mathrm{RR}$ activity observed upon axial coordination to $\mathrm{CoPc}$ is due to the increased energy of the $\mathrm{dz}^{2}$ orbital, and highlight an important design consideration for macrocyclic $\mathrm{MN}_{4}$-based electrocatalysts.

\section{INTRODUCTION}

The electrochemical conversion of $\mathrm{CO}_{2}$ into energy-rich fuels and chemicals in the $\mathrm{CO}_{2}$ reduction reaction $\left(\mathrm{CO}_{2} \mathrm{RR}\right)$ has gained significant interest as a promising strategy for effectively storing intermittent renewable energy from sources such as solar and wind. ${ }^{1-14}$ There is an increasing drive to discover new catalysts that reduce $\mathrm{CO}_{2}$ into value-added products or chemical feedstocks, including $\mathrm{CO},{ }^{12-14}$ with high activity and selectivity at low overpotentials. Physically-motiviated design principles help guide the rational design of new $\mathrm{CO}_{2} \mathrm{RR}$ catalyst systems, and these design principles can be tested and verified by evaluation of how systematic modifications of catalyst model systems influence electrocatalytic activity and selectivity. Surface-immobilized cobalt phthalocyanine $(\mathrm{CoPc})$ is a model system of particular interest to the electrocatalysis community; it was first reported as an active catalyst for the $\mathrm{CO}_{2} \mathrm{RR}$ over 35 years ago, ${ }^{15,16}$ and since then its catalytic activity has been extensively explored under various aqueous conditions. ${ }^{17-42}$

Our group's interest in CoPc lay in its utility as a model system for studying the effects of polymer encapsulation on electrocatalytic performance. In particular, we are interested in probing how changing a catalyst's coordination environment due to polymer encapsulation influences its electrocatalytic activity and selectivity for multielectron small-molecule transformations such as the $\mathrm{CO}_{2} \mathrm{RR} .{ }^{43}$ Physisorbed CoPc on carbon electrodes with no polymer binder shows only modest activity for the $\mathrm{CO}_{2} \mathrm{RR}$ in aqueous phosphate and citrate solutions with appreciable $\mathrm{H}_{2}$ generated from the competitive hydrogen evolution 
reaction (HER). ${ }^{15,17,18,21,22}$ Work by our group ${ }^{17,19}$ and others ${ }^{21,22}$ has shown that encapsulating CoPc within coordinating polymers like poly-4-vinylpyridine (P4VP) results in CoPc-P4VP composite materials that operate with increased activity and selectivity for the electrochemical reduction of $\mathrm{CO}_{2}$ to $\mathrm{CO}$ compared to the parent physisorbed $\mathrm{CoPc}$ complexes. This increase in activity and selectivity has been attributed to three distinct effects of the polymer on the coordination environment of the Co active site in CoPc-P4VP: i) axial-coordination of pyridyl in P4VP to the Co center increases the catalyst's nucleophilicity for $\mathrm{CO}_{2}$ binding, ii) $\mathrm{H}$-bonding interactions that stabilize reactive $\mathrm{CO}_{2}$ intermediates, and iii) control of $\mathrm{H}^{+}$delivery through a multi-site proton relay mechanism involving the polymer's pyridyl residues (Figure 1). ${ }^{17,18,22}$ Axial coordination plays an important role in modulating the activity ${ }^{17,18,23,29}$ and mechanism ${ }^{18,19}$ of the $\mathrm{CO}_{2} \mathrm{RR}$ by $\mathrm{CoPc}$ systems. For instance, we have previously shown that upon axial coordination of pyridine $=\mathrm{L} 3$ to $\mathrm{CoPc}$ to form the $\mathrm{CoPc}(\mathrm{L} 3)$ complex, there is a change in the ratedetermining step of the mechanism from an initial $\mathrm{CO}_{2}$ coordination step for CoPc to a subsequent protonation event for $\operatorname{CoPc}(\mathrm{L} 3) .{ }^{18}$ 


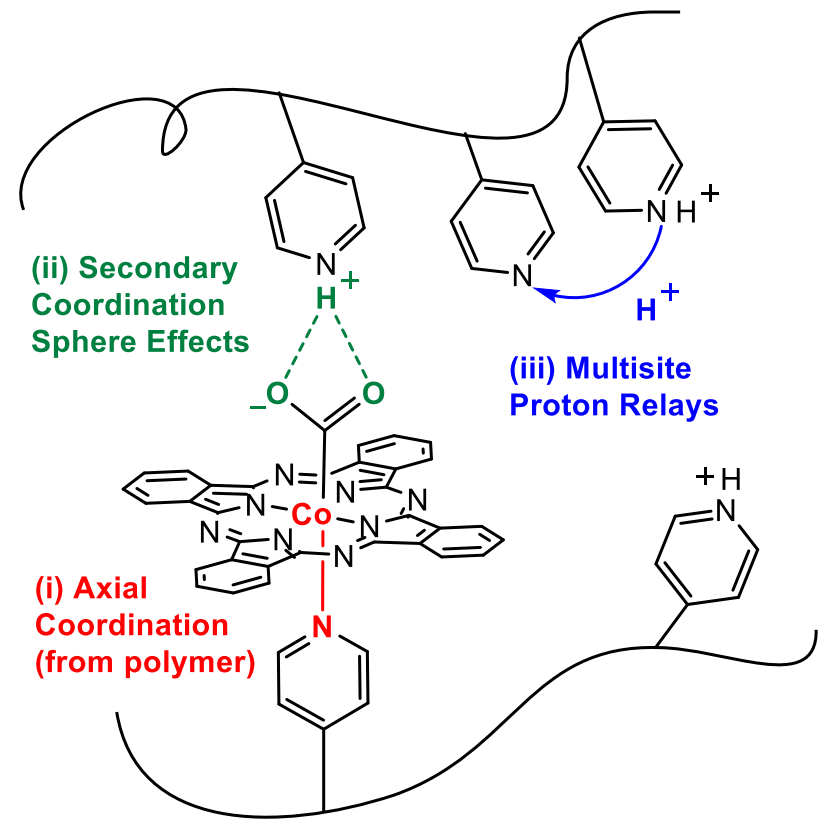

Figure 1. Illustration of CoPc-P4VP highlighting the i) axial-coordination to the pyridyl residues from the P4VP polymer in the primary coordination sphere, ii) the H-bonding stabilization of reduced $\mathrm{CO}_{2}$ intermediates in the secondary coordination sphere, and iii) the controlled $\mathrm{H}^{+}$delivery via a multisite proton relay in the outer coordination sphere. Adapted from Ref. 19 with permission from The Royal Society of Chemistry.

Based on the studies described above, we hypothesize that axial coordination of $\sigma$-donating ligands (L) to CoPc increases the nucleophilicity of the Co center in the $\mathrm{CoPc}(\mathrm{L})$ complexes by increasing the energy of the $\mathrm{dz}^{2}$ orbitals. This, in turn, increases the ability of the Co center to coordinate and activate the Lewis acidic carbon of $\mathrm{CO}_{2}$. Based on this hypothesis, we expect that increasing the $\sigma$-donating ability of the axial ligand on $\operatorname{CoPc}(\mathrm{L})$ should further increase the relative energy of the $\mathrm{dz}^{2}$ orbital resulting in higher activity for the $\mathrm{CO}_{2} \mathrm{RR}$. In this report, we test this hypothesis by conducting a combined electrochemical and computational study on $\mathrm{CoPc}(\mathrm{L})$ complexes with various axial ligands (L). A list of the axial ligands used in this study are shown in Figure 2 in order of increasing $\sigma$-donor strength from 
lowest (L1) to highest (L8) as indicated by the reported coupling constant between the donor group and the methylmercury (II) cation. ${ }^{44-48}$ We demonstrate that as the $\sigma$-donor strength of the axial ligand increases, there is a corresponding increase in the catalytic activity of the $\mathrm{CoPc}(\mathrm{L})$ for the $\mathrm{CO}_{2} \mathrm{RR}$. Using density functional theory analysis, we show that axial coordination does, in fact, increase the energy of the $\mathrm{dz}^{2}$ orbital, and that the experimentally-observed increase in $\mathrm{CO}_{2} \mathrm{RR}$ activity with increasing $\sigma$-donor strength of the axial ligand is correlated to an increased extent of charge transfer from the reduced CoPc(L) complex to $\mathrm{CO}_{2}$ adduct. Overall, our work highlights the role of axial coordination in modulating activity for the $\mathrm{CO}_{2} \mathrm{RR}$ and provides important insights into the design of highly active CoPc-based systems for selective $\mathrm{CO}_{2}$ conversion.

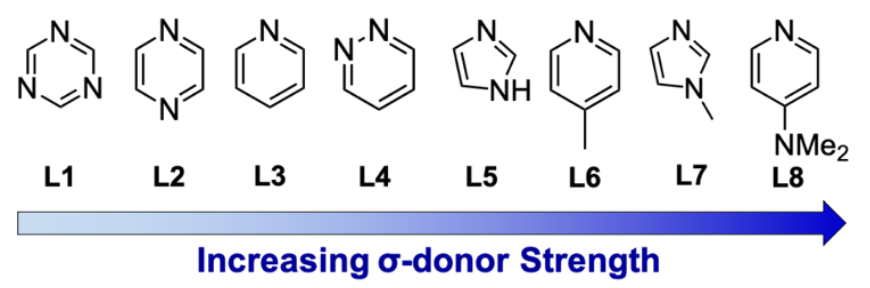

Figure 2. Axially-coordinating ligands (L) investigated in this study, listed in order of increasing $\sigma$-donor strength from lowest $(\mathrm{L} 1)$ to highest $(\mathrm{L} 8) . \mathrm{L} 1=1,3,5$-triazine, $\mathrm{L} 2=$ pyrazine, $\mathrm{L} 3=$ pyridine, L4 = pyridazine, L5 = imidazole, L6 = 4-methylpyridine, L7 = 1-methyl imidazole, and L8 = 4-dimethylaminopyridine.

\section{EXPERIMENTAL}

\section{Materials and Supplies}

All purchased chemicals were used as received unless otherwise specified. Cobalt phthalocyanine (CoPc, 97\%), N,N-dimethylformamide (DMF, ACS grade), 1,3,5-triazine (L1, 97\%), pyrazine (L2, $>99 \%$ ), pyridine (L3, ACS grade, $\geq 99 \%$ ), pyridazine (L4, 98\%), imidazole (L5, 99\%), 4-methyl pyridine 
(L6, 99\%), 1-methyl imidazole (L7, $\geq 99 \%$ ), 4-dimethylaminopyridine (L8, $\geq 99 \%$ ), sodium phosphate monobasic (BioXtra, > 99.0\%), ferrocenecarboxylic acid (97\%), and sodium hydroxide (NaOH, BioXtra, $\geq 98 \%$ were purchased from Sigma Aldrich. Nitric acid $\left(\mathrm{HNO}_{3}\right.$, TraceMetal grade, $\left.67-70 \%\right)$ was purchased from Fisher Scientific. Nafion-117 cation exchange membranes (Nafion) were purchased from the Fuel Cell Store. Nitrogen $\left(\mathrm{N}_{2}\right)$ was boil-off gas from a liquid nitrogen source. Compressed $\mathrm{CO}_{2}$ gas (99.8\%) was purchased from Cryogenic Gases. All water used in this study was ultrapure water (18.2 $\mathrm{M} \Omega \cdot \mathrm{cm}$ resistivity) purified with a Thermo Scientific GenPure UV-TOC/UF xCAD-plus water purification system.

\section{Preparation of $\mathrm{CoPc}(\mathrm{L})$-modified Edge Plane Graphite Electrodes}

Deposition solutions for $\mathrm{CoPc}$ and $\operatorname{CoPc}(\mathrm{L})$ were prepared based on an adaptation of previously described procedure. ${ }^{18} 0.05 \mathrm{mM} \mathrm{CoPc} / \mathrm{DMF}$ deposition solutions were prepared by dissolving $0.13 \mathrm{mg}$ of CoPc in $45 \mathrm{~mL}$ DMF and sonicating for at least $30 \mathrm{~min}$ until the CoPc was fully dispersed. To prepare $\mathrm{CoPc}(\mathrm{L}) / \mathrm{DMF}$ deposition solutions, $2.25 \mathrm{mmol}$ of the axial ligand $\mathrm{L}$ was added to $45 \mathrm{~mL}$ of the $0.05 \mathrm{mM}$ $\mathrm{CoPc} / \mathrm{DMF}$ deposition solution, and the resulting solution was sonicated for at least 30 min until the CoPc and $\mathrm{L}$ were fully dispersed. Note that for the liquid ligands $\mathrm{CoPc}(\mathrm{L} 3), \mathrm{CoPc}(\mathrm{L} 4), \mathrm{CoPc}(\mathrm{L} 6)$ and $\mathrm{CoPc}(\mathrm{L} 7)$ in DMF deposition solution, the CoPc and Ligands were dissolved with $10 \mathrm{~mL}$ of DMF, it was vortexed for $1 \mathrm{~min}$ and sonicated for $10 \mathrm{~min}$ prior the addition of the remainding $35 \mathrm{~mL}$ DMF to favor the complex formation. For the solid ligands $\operatorname{CoPc}(\mathrm{L} 1), \operatorname{CoPc}(\mathrm{L} 2), \operatorname{CoPc}(\mathrm{L} 5)$ and $\mathrm{CoPc}(\mathrm{L} 8)$ in DMF deposition solutions, $\sim 60 \mathrm{~min}$ of sonication time was used to ensure full dispersion of $\mathrm{CoPc}$ and $\mathrm{L}$. The final concentrations in the $\mathrm{CoPc}(\mathrm{L}) / \mathrm{DMF}$ deposition solutions was $0.05 \mathrm{mM} \mathrm{CoPc}$ and $50 \mathrm{mM} \mathrm{L}$. The large excess of the axial ligand $(\sim 1,000 \times)$ used in the deposition solutions was to ensure equilibrium favored the axially-coordinated species. ${ }^{49}$ 
Prior to deposition, $5 \mathrm{~mm}$ diameter edge plane graphite (EPG) disk electrodes (3.81 mm EPG disk encapsulated in epoxy, $0.114 \mathrm{~cm}^{2}$ effective surface area, Pine Research Instrumentation) were manually polished with 600 grit $\mathrm{SiC}$ grinding paper (Buehler CarbiMet) followed by sonication in ultrapure water for $\sim 1$ min. The CoPc- and $\mathrm{CoPc}(\mathrm{L})$-modified $\mathrm{CoPc}$ EPG working electrodes were then prepared by dropcasting $5 \mu \mathrm{L}$ of the $\mathrm{CoPc} / \mathrm{DMF}$ deposition solution or the $\mathrm{CoPc}(\mathrm{L}) / \mathrm{DMF}$ deposition solution onto the EPG electrode. The disk electrodes were then placed in a drying oven at $\sim 60-70{ }^{\circ} \mathrm{C}$ for $\sim 15$ min to allow the solvent to evaporate. The resulting loading of $\mathrm{CoPc}$ or $\operatorname{CoPc}(\mathrm{L})$ on the electrode surface is calculated as $2.19 \times 10^{-9} \mathrm{~mol} \mathrm{~cm}^{-2}$.

\section{Electrochemical Measurements}

Electrochemical measurements were conducted using a Bio-Logic SP200 potentiostat, and data were recorded using the Bio-Logic EC-Lab software package. Reference electrodes were commercial saturated calomel electrodes (SCE, $\mathrm{CH}$ Instruments) externally referenced to ferrocenecarboxylic acid in $0.2 \mathrm{M}$ phosphate buffer at $\mathrm{pH} 7\left(0.284 \mathrm{~V}\right.$ vs. SCE),${ }^{50}$ and auxiliary electrodes were carbon rods $(99.999 \%$, Strem Chemicals Inc.). Unless otherwise noted, all electrochemical measurements were conducted at least three times with independently prepared electrodes, and reported values are the averages of these repetitions with standard deviations included as the reported errors. The electrolyte solution used for all electrochemical studies was a pH 5 phosphate solution prepared from a $0.1 \mathrm{M} \mathrm{NaH}_{2} \mathrm{PO}_{4}$ solution adjusted to $\mathrm{pH} 5$ by the addition of aqueous $1 \mathrm{M} \mathrm{NaOH}$. The solution $\mathrm{pH}$ was confirmed using a Fisher Scientific Accumet AB200 pH meter with an Accumet pH/ATC Epoxy Body Combination Electrode calibrated with a 3-point calibration curve at $\mathrm{pH}=4.01,7.00$, and 10.01 .

Rotating Disk Electrode Voltammetry and Chronoamperometry Experiments. For rotating disk electrode voltammetry (RDEV) experiments and rotating disk electrode chronoamperometric step (RDE- 
CA) measurements, the working electrodes were mounted into a Pine Research Instrumentation E6-series Change Disk rotating disk electrode (RDE) assembly attached to an MSR rotator. RDEV and RDE-CA measurements were conducted at room temperature in a custom two-compartment glass $\mathrm{H}$-cell as previously described. ${ }^{18}$ The working and reference electrodes were submerged in $\sim 30 \mathrm{~mL}$ solution in the first compartment, and the auxiliary electrode was submerged in $\sim 15 \mathrm{~mL}$ solution in the second compartment. The two compartments were separated by a Nafion cation exchange membrane. Both compartments were sparged with $\mathrm{CO}_{2}$ for $\sim 30$ min prior to each set of measurements, and the headspace was blanketed with $\mathrm{CO}_{2}$ during the measurements. The $\mathrm{CO}_{2}$ used was first saturated with electrolyte solution by bubbling through a gas washing bottle filled with the same electrolyte solution used in the cell to minimize electrolyte evaporation in the cell during the measurements. RDEV measurements were measured at $1600 \mathrm{rpm}$ rotation rate and a scan rate of $1 \mathrm{mV} \mathrm{s}^{-1}$. RDE-CA measurements were conducted at $1600 \mathrm{rpm}$ with 2 -min potential steps from $-0.95 \mathrm{~V}$ to $-1.35 \mathrm{~V}$ vs. SCE at $0.05 \mathrm{~V}$ increments. The 1600 rpm rotation rate was meant to ensure steady-state delivery of substrate to our surface to allow for accurate comparisons of catalytic rates. Note that $1600 \mathrm{rpm}$ does not imply kinetically-limiting conditions - mass transport to catalyst sites in non-uniform catalyst-polymer composite films is not governed by simple Koutecký-Levich kinetics. ${ }^{51-54}$ The uncompensated resistance of the cell $\left(\mathrm{R}_{\mathrm{u}}\right)$ was measured with a singlepoint high-frequency impedance measurement, and RDEV and RDE-CA measurements were corrected for IR-drop at $85 \%$ through positive feedback using the Bio-Logic EC-Lab software. In general, our electrochemical cell for RDEV and RDE-CA measurements had $\mathrm{R}_{\mathrm{u}} \approx 100 \Omega$ when filled with our pH 5 phosphate electrolyte solution.

Controlled Potential Electrolysis Experiments. Controlled potential electrolyses (CPE) were conducted at room temperature in a custom, gas-tight two compartment U-cell as previously described. ${ }^{18}$ The working electrode was held in a RDE internal hardware kit (Pine Research Instrumentation) and 
mounted into a custom-designed PEEK sleeve. The first compartment of the U-cell held the working electrode and reference electrode in $25 \mathrm{~mL}$ of electrolyte, and the second compartment held the auxiliary electrode in $\sim 15 \mathrm{~mL}$ electrolyte. The two compartments were separated by a Nafion cation exchange membrane. The total volume of the first chamber was measured after each experiment by measuring the volume of $\mathrm{H}_{2} \mathrm{O}$ necessary to completely fill the chamber when the cell was fully assembled with the working and reference electrodes, and the headspace volume for the CPE measurements was calculated by subtracting the electrolyte volume of $25 \mathrm{~mL}$ from the total volume of the first chamber. Prior to each experiment, both chambers were sparged with $\mathrm{CO}_{2}$ for $\sim 30 \mathrm{~min}$ and then the main chamber was sealed under $\mathrm{CO}_{2}$ atmosphere. The uncompensated resistance of the cell was measured with a single-point highfrequency impedance measurement. In general, our electrochemical cell for CPE had $\mathrm{R}_{\mathrm{u}}=\sim 200 \Omega$ in $\mathrm{pH}$ 5 phosphate solution. The CPE measurements were conducted with no iR compensation, and the reported electrolysis potentials are the actual applied potentials.

Product detection and quantification were conducted as previously described. ${ }^{18} \mathrm{CO}$ and $\mathrm{H}_{2}$ were detected on a Thermo Scientific Trace 1310 Gas Chromotography system with two analyzer channels for the detection of $\mathrm{H}_{2}$ and $\mathrm{C} 1-\mathrm{C} 2$ products. After each electrolysis, a $5 \mathrm{~mL}$ aliquot of the headspace in the first compartment of the cell was collected using a Pressure-Lok gastight syringe $(10 \mathrm{~mL}$, Valco VICI Precision Sampling, Inc.), and the aliquot was injected into a $3 \mathrm{~mL}$ sample loop on the gas chromatograph. Using a custom valve system, column configuration, and method provided by Thermo Scientific, gases were separated such that $\mathrm{H}_{2}$ was detected on the first channel using an Ar carrier gas and thermal conductivity detector (TCD), and all other gases were detected on the second channel using a He carrier gas and a TCD. The GC system was calibrated using calibration gas mixtures (SCOTTY Specialty Gas) at $\mathrm{H}_{2}=0.02,0.05,0.5$, and $1 \% \mathrm{v} / \mathrm{v}$, and $\mathrm{CO}=0.02,0.05,0.5,1$, and $7 \% \mathrm{v} / \mathrm{v}$. Chromatographs were analyzed using the Chromeleon Console Workstation software. To determine the concentration of 
dissolved products in the electrolyte solution, $1 \mathrm{~mL}$ aliquots of the post-electrolysis solutions were analyzed using a Thermo Scientific UltiMate 3000 HPLC system equipped with a refractive index detector (RFD), a $5 \mathrm{~cm}$ Thermo Scientific ${ }^{\mathrm{TM}}$ HyperREZ ${ }^{\mathrm{TM}}$ XP Carbohydrate $\mathrm{H}^{+}$LC guard column and a $30 \mathrm{~cm}$ Thermo Scientific ${ }^{\mathrm{TM}}$ HyperREZ ${ }^{\mathrm{TM}}$ XP Carbohydrate $\mathrm{H}^{+} \mathrm{LC}$ analytical column in series using a $5 \mathrm{mM}$ $\mathrm{H}_{2} \mathrm{SO}_{4}$ aqueous mobile phase at a constant temperature of $50^{\circ} \mathrm{C}$. The detection limit of the HPLC for formic acid was determined to be $0.1 \mathrm{mM}$. No formic acid was observed after the $\mathrm{CO}_{2} \mathrm{RR} C P E s$.

Faradaic Efficiencies (FE) were calculated by dividing the moles of each product detected by the total moles of electrons based on the charge passed during the CPE according to Equation 1:

$$
F E=\frac{\frac{V_{\mathrm{HS}}}{V_{\mathrm{m}}} \times C \times n F}{Q} \times 100 \%
$$

Here, $V_{\mathrm{HS}}$ is the volume of the headspace in the first chamber of the electrolysis cell, $V_{\mathrm{m}}=24.5 \mathrm{~L} \mathrm{~mol}^{-1}$ is the molar volume of gas at $25^{\circ} \mathrm{C}$ and $1.0 \mathrm{~atm}, \mathrm{C}$ is the volume percent of the $\mathrm{CO}$ or $\mathrm{H}_{2}$ product detected by $\mathrm{GC}, n=2$ is the number of electrons passed per reaction for the production of $\mathrm{CO}$ or $\mathrm{H}_{2}, F=96,485 \mathrm{C}$ mol $^{-1}$ is Faraday's constant, and $Q$ is the amount of charge passed during the CPE measurement.

\section{UV-Vis Spectroscopy}

$0.01 \mathrm{mM} \mathrm{CoPc} / \mathrm{DMF}$ and $\mathrm{CoPc}(\mathrm{L}) / \mathrm{DMF}$ solutions were analyzed using PerkinElmer Lambda 265 UV-Vis Spectrophotometer with fast mode and baseline correction. The $0.01 \mathrm{mM}$ solutions were prepared by diluting the corresponding $0.05 \mathrm{mM} \mathrm{CoPc} / \mathrm{DMF}$ and $\mathrm{CoPc}(\mathrm{L}) / \mathrm{DMF}$ deposition solutions described above.

\section{Density Functional Theory Calculations}

All quantum-chemical calculations utilized density functional theory as implemented in the Q-Chem 5.1 software package. ${ }^{55}$ The B3LYP density functional with the 6-31G** basis function was employed for 
the gas-phase geometry optimization of the $\operatorname{CoPc}(\mathrm{L})$ systems. Single point calculations were employed to calculate the orbitals energies using B3LYP in combination with $6-311+\mathrm{G}^{* *}$ basis on all atoms except def2-TZVP on the Co atom. To obtain the binding energy $(\mathrm{BE})$ of $\mathrm{CO}_{2}$ to the neutral and reduced $\mathrm{CoPc}(\mathrm{L})$ complexes structures were optimized with $\omega \mathrm{B} 97 \mathrm{X}-\mathrm{D}$ and the $6-31 \mathrm{G}^{* *}$ basis, which accurately captures non-covalent interactions. ${ }^{56}$ In the optimization of the reduced $\mathrm{CoPc}(\mathrm{L})$ complexes, the axial coordinating ligands were fixed in the XY plane to prevent $\pi$-stacking interactions between the ligand and the phthalocyanine rings. The reported energies were obtained using $\omega \mathrm{B} 97 \mathrm{X}-\mathrm{D}$ and the $6-31+\mathrm{G}^{* *}$ basis to better describe negatively charged ions. ${ }^{38}$ Solvation energies were calculated using SMD $^{57}$ to model the implicit water solvent effect.

The Absolutely Localized Molecular Orbital-Charge Transfer Analysis (ALMO-CTA) ${ }^{58}$ was used quantify electron donation within the CoPc unit and its ligands. The systems were divided into two fragments to study the forward charge transfer from: (1) ligands to the CoPc, (2) five-coordinate $\mathrm{CoPc}(\mathrm{L})$ complexes to the $\mathrm{CO}_{2}$ adduct, and (3) five-coordinate complexes to the protonated $\mathrm{CO}_{2}$ adduct. Reported forward CTA terms for neutral, reduced, $\mathrm{CO}_{2}$ adsorbed $\mathrm{CoPc}(\mathrm{L})$ are obtained at the $\omega \mathrm{B} 97 \mathrm{X}-\mathrm{D} / \mathrm{def} 2-\mathrm{SVP}$ level of theory, while the protonated $\mathrm{CO}_{2}$ adduct intermediate was obtain with B3LYP/def2-SVP. Additionally, the forward charge transfer from the reduced $\mathrm{CoPc}(\mathrm{L})$ species to the $\mathrm{CO}_{2}$ adduct was calculated to obtain quantitative insight on the catalytically active species nucleophilic capacities.

\section{RESULTS AND DISCUSSION}

The core hypothesis we are testing in this study is that axial coordination of ligands $\mathrm{L}$ to CoPc makes the Co center more nucleophilic in the resulting $\operatorname{CoPc}(\mathrm{L})$ complexes, and that this increased nucleophilicity translates into an increase in activity for the $\mathrm{CO}_{2} \mathrm{RR}$ compared to the four coordinate CoPc. A corollary to this hypothesis is that the nucleophilicity of the Co center in $\operatorname{CoPc}(\mathrm{L})$, and therefore the 
$\mathrm{CO}_{2} \mathrm{RR}$ activity, should be correlated to the $\sigma$-donor strength of the axial ligand. To test this hypothesis, we have conducted a combined experimental and computational study that explores how the catalytic activity and electronic structure of $\mathrm{CoPc}(\mathrm{L})$ changes as we modulate the $\sigma$-donor strength of $\mathrm{L}$.

\section{Effect of $\sigma$-donor Strength of Axial Ligands on $\mathrm{CO}_{2} \mathrm{RR}$ Activity by $\mathrm{CoPc}(\mathrm{L})$}

To experimentally quantify the relative $\sigma$-donor strength of the axial ligands in $\operatorname{CoPc}(\mathrm{L})$ catalysts, we measured how axial ligation influences the $\lambda_{\max }$ of the $\mathrm{Q}$ band of $\mathrm{CoPc}(\mathrm{L})$. For the four-coordinate $\mathrm{CoPc}$ complex, the measured $\mathrm{Q}$ band has $\lambda_{\max }=659 \mathrm{~nm}$ (Figure $\mathrm{S} 1$ ). When adding an axial ligand $\mathrm{L}$ to form $\operatorname{CoPc}(\mathrm{L})$, there is a red shift in the $\lambda_{\max }$ of the $\mathrm{Q}$ band attributed to the increased electron density on the central metal atom, ${ }^{49,59-61}$ and the extent of the red shift should be directly correlated to the electrondonating ability of the ligand L (Figure S1) ${ }^{61}$ The $\lambda_{\max }$ of the red-shifted Q bands for $\operatorname{CoPc}(\mathrm{L})$ solutions with axial ligands L1-L8 are shown in Figure 3. The shift in the Q-band is consistent with the postulated ordering of the $\sigma$-donor strength of the ligands L1-L8 shown in Figure 2. 


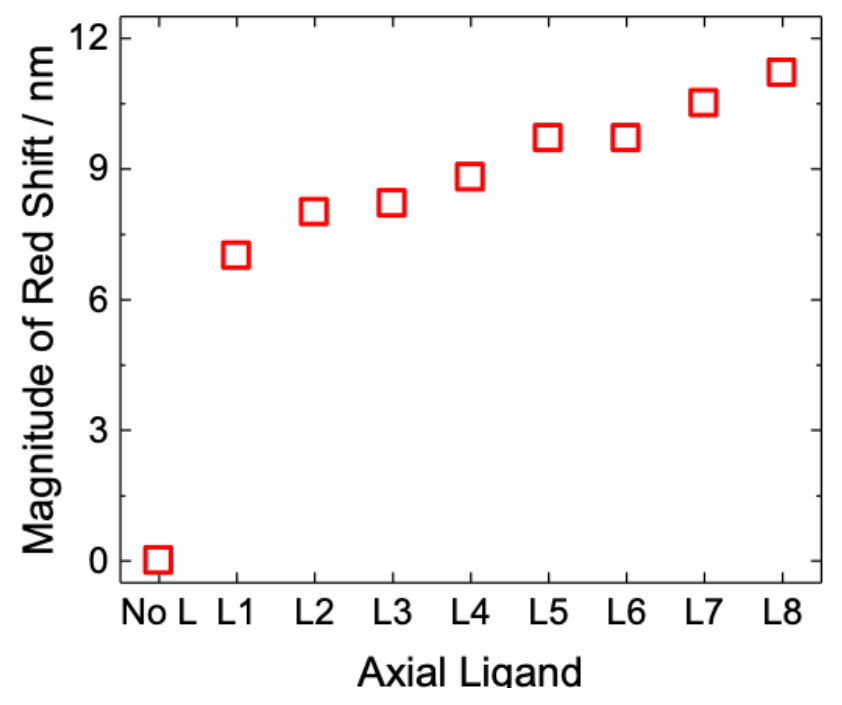

Figure 3. Magnitude of the red shift of the Q-band for solutions of $\operatorname{CoPc}(\mathrm{L})$ with axiallycoordinated ligands L1-L8 compared to the $\lambda_{\max }=659 \mathrm{~nm}$ of the CoPc without any axiallycoordinated ligand (No L).

To investigate the influence of $\sigma$-donor strength of the axial ligand on $\mathrm{CO}_{2} \mathrm{RR}$ activity, we evaluated the $\mathrm{CO}_{2} \mathrm{RR}$ activity physisorbed $\mathrm{CoPc}(\mathrm{L})$ catalysts on edge-plane graphite $(\mathrm{EPG})$ surfaces using rotating disk electrode voltammetry (RDEV) at $1600 \mathrm{rpm}$ and $1 \mathrm{mV} \mathrm{s}^{-1}$ scan rate. The RDEV measurements were conducted at $1600 \mathrm{rpm}$ and $1 \mathrm{mV} \mathrm{s}{ }^{-1}$ scan rate. This scan rate is slow enough to ensure steady-state behavior at the electrode surface, and the rotation rate is sufficiently fast to aid in product removal and limit bubble formation from evolved $\mathrm{CO}$ and $\mathrm{H}_{2}$ at the electrode surface. The resulting average RDEVs of $\mathrm{CoPc}, \mathrm{CoPc}(\mathrm{L} 1)$ and $\mathrm{CoPc}(\mathrm{L} 8)$ for the $\mathrm{CO}_{2} \mathrm{RR}$ are shown in Figure 4, and the average RDEVs of all complexes are shown in Figure S2. To confirm that the RDEV measurements are a true measure of steady state behavior, a series of rotating disk electrode chronoamperometric (RDE-CA) steps were measured for each catalyst (Figure S2). In these experiments, the potential was held constant at given applied potentials for $2 \mathrm{~min}$ at $1600 \mathrm{rpm}$ rotation rate, and the current was allowed to decay to a steady state value. Average steady-state currents for the $\mathrm{CO}_{2} \mathrm{RR}$ by each $\mathrm{CoPc}(\mathrm{L})$ complex investigated as determined from RDE-CA 
measurements show good agreement when overlaid with the RDEV measurements (Figure 4), suggesting that the RDEV measurements are valid approximations of steady-state behavior.

For each $\operatorname{CoPc}(\mathrm{L})$ complex investigated, there is a plateau in the catalytic RDEV at $\sim-1.25 \mathrm{~V}$ vs. SCE, and we attribute this plateau current to the maximum $\mathrm{CO}_{2} \mathrm{RR}$ activity under the experimental conditions. Therefore, the activity and selectivity at $-1.25 \mathrm{~V}$ vs. SCE was used as the primary metric to compare the $\mathrm{CO}_{2} \mathrm{RR}$ performance for the $\mathrm{CoPc}(\mathrm{L})$ catalysts. The average current densities measured from the catalytic RDE-CA measurements are summarized in Table S2. A plot of the catalytic current density at $-1.25 \mathrm{~V}$ for each $\operatorname{CoPc}(\mathrm{L})$ catalyst as a function of the magnitude of the red shift of the complexes' $\mathrm{Q}$ bands, a proxy for the $\sigma$-donor strength of the axial ligands, is shown in Figure 5a. As the $\sigma$-donor strength increases and the magnitude of the red shift increases, there is a corresponding increase in the catalytic current density. This activity trend is consistent with our hypothesis that increasing the $\sigma$-donor strength of the axial ligand in $\operatorname{CoPc}(\mathrm{L})$ correspondingly increases the nucleophilicity of the Co center, facilitating $\mathrm{CO}_{2}$ activation and reduction. 


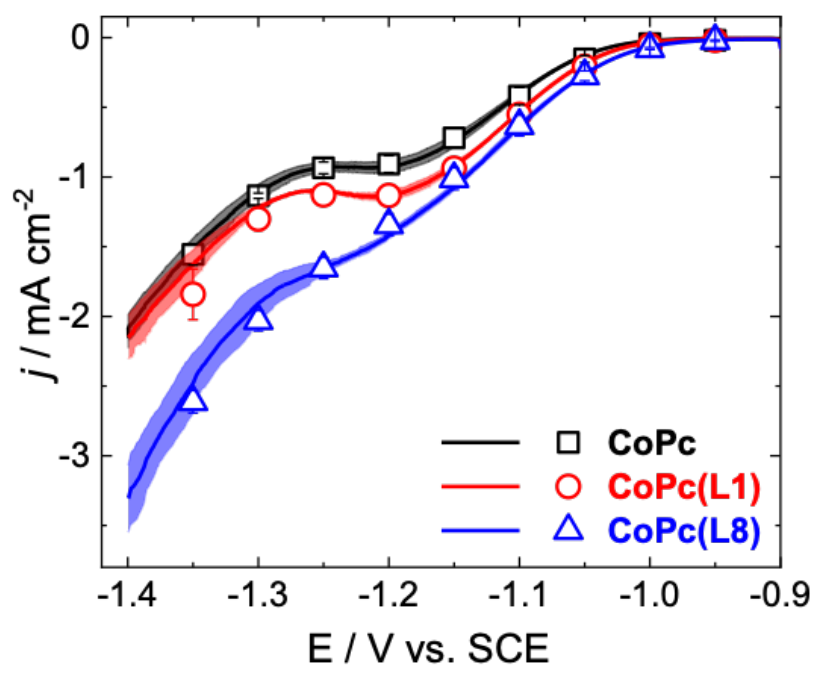

Figure 4. (a) Rotating disk electrode voltammograms (RDEVs) of the CO2RR by CoPc, $\mathrm{CoPc}(\mathrm{L} 1)$, and $\mathrm{CoPc}(\mathrm{L} 8)$ catalysts at $1 \mathrm{mV} \mathrm{s}-1$ scan rate and $1600 \mathrm{rpm}$ in $\mathrm{CO} 2$-saturated $\mathrm{pH} 5$ phosphate solutions. The solid lines represent the averages RDEVs from at least three measurements on independently prepared samples, and the shaded region represents the standard deviation for these measurements. The average results of 2 min rotating disk electrode chronoamperometric (CA) steps from at least three measurements on independently prepared samples are shown by open symbols, and the error bars represent standard deviations for these measurements. The close overlay of the RDEV and CA data suggests that the RDEV measurements are a good approximation of steady-state conditions. 

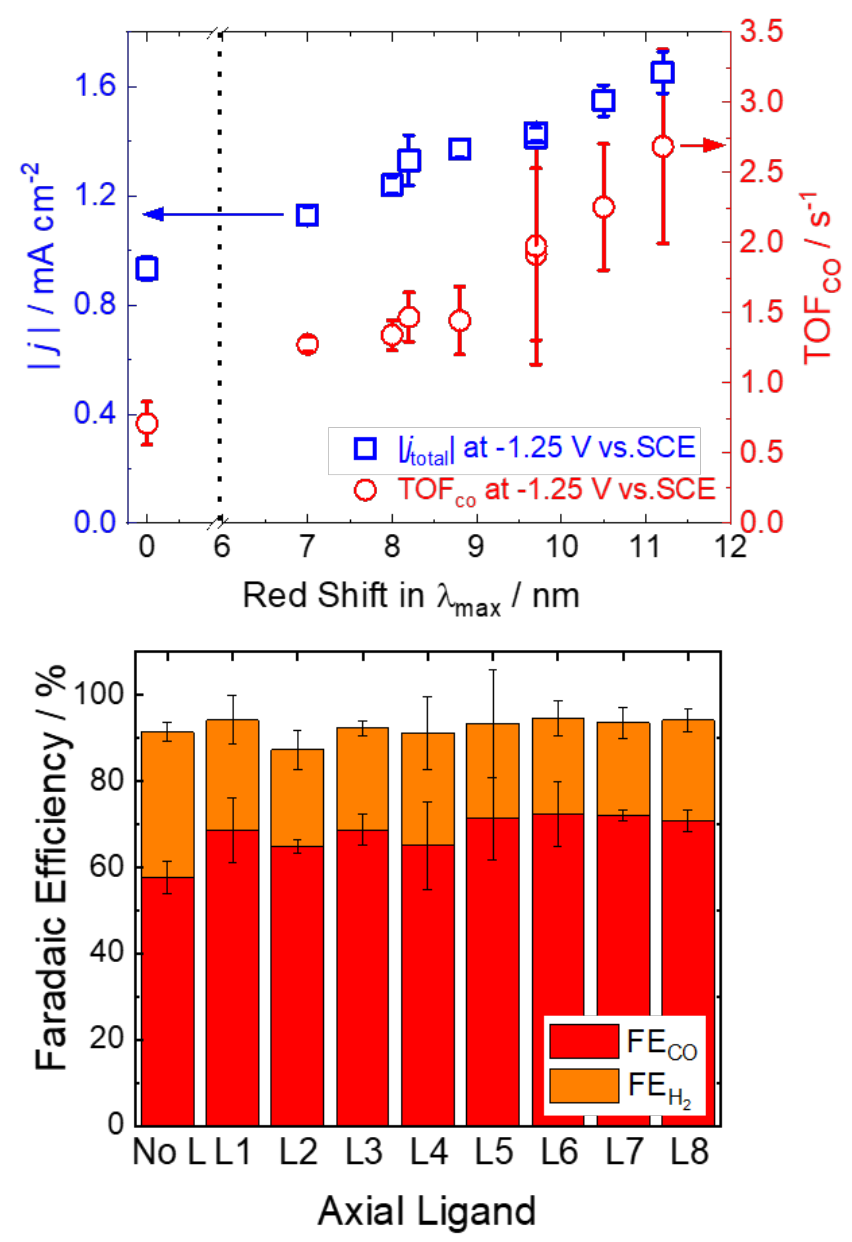

Figure 5. (a) A plot of the absolute value of the average current density from RDE-CA measurements (left y-axis) and turnover frequency, $\mathrm{TOF}_{\mathrm{CO}}$, from the $\mathrm{CPE}$ measurements (right $\mathrm{y}$-axis) at $-1.25 \mathrm{~V}$ vs SCE as a function of the red shift in $\lambda_{\max }$ for $\operatorname{CoPc}(\mathrm{L})$ which is related to the $\sigma$-donor ability of the axial ligands, L. Note the vertical dotted line highlights a break in the $\mathrm{x}$-axis at $\lambda_{\max }=1 \mathrm{~nm}$, and the scale continues after the break at $\lambda_{\max }=6 \mathrm{~nm}$. (b) A plot of the average Faradaic efficiencies for $\mathrm{CO}$ and $\mathrm{H}_{2}$ production from $\mathrm{CPE}$ measurements at $-1.25 \mathrm{~V}$ vs SCE. For both (a) and (b), the data shown are averages from at least three experiments on independently prepared samples, and the error bars represent standard deviations. 
Controlled potential electrolysis (CPE) were performed at $-1.25 \mathrm{~V}$ vs. SCE to assess Faradaic efficiencies for $\mathrm{CO}_{2}$ reduction to $\mathrm{CO}\left(\mathrm{FE}_{\mathrm{CO}}\right)$ by $\mathrm{CoPc}$ and $\mathrm{CoPc}(\mathrm{L})$ modified electrodes. Electrolyses were conducted in a sealed electrochemical cell in $\mathrm{CO}_{2}$ atmosphere for $2 \mathrm{~h}$, and $\mathrm{CO}$ and $\mathrm{H}_{2}$ evolved were quantified from headspace analysis using gas chromatography. Representative examples of the CPE current traces are shown in Figures S3-S11 for each catalyst, and the resulting Faradaic efficiencies for $\mathrm{H}_{2}\left(\mathrm{FE}_{\mathrm{H}}\right)$ and $\mathrm{CO}\left(\mathrm{FE}_{\mathrm{CO}}\right)$ generation are summarized in Figure $5 \mathrm{~b}$ and Table $\mathrm{S} 1$. In general, the only products produced were $\mathrm{CO}$ and $\mathrm{H}_{2}$. All $\mathrm{CoPc}(\mathrm{L})$ catalysts reduce $\mathrm{CO}_{2}$ to $\mathrm{CO}$ with $\mathrm{FE}_{\mathrm{CO}} \approx 70 \%$, and $\mathrm{CoPc}$ with no axial ligand produces $\mathrm{CO}$ with $\mathrm{FE}_{\mathrm{CO}} \approx 60 \%$. Note that control $\mathrm{CPE}$ experiments of the $\mathrm{EPG}$ background under identical conditions showed only $\mathrm{H}_{2}$ as the sole product, confirming that the adsorbed $\operatorname{CoPc}(\mathrm{L})$ complexes are the active species for the $\mathrm{CO}_{2} \mathrm{RR}$. The increased FE for $\mathrm{CoPc}(\mathrm{L})$ compared to $\mathrm{CoPc}$ is consistent with our previous findings that axial coordination of ligands such as pyridine to the CoPc complex facilitate $\mathrm{CO}_{2}$ coordination by shifting the rate determining step from an initial $\mathrm{CO}_{2}$ binding step to a subsequent protonation event. ${ }^{18}$ The fact that all the $\mathrm{CoPc}(\mathrm{L})$ systems show the same $\mathrm{FE}$ for $\mathrm{CO}$ production suggests that this change in the rate-determining step upon axial coordination occurs for all $\operatorname{CoPc}(\mathrm{L})$ systems investigated independent of $\sigma$-donor ability of the axial ligand. A plot of the electrocatalytic turnover frequencies for $\mathrm{CO}$ production $\left(\mathrm{TOF}_{\mathrm{CO}}\right)$ determined from the $\mathrm{CPE}$ measurements as function of the magnitude of the red shift of the complexes' Q bands shows increasing activity with increasing $\sigma$-donor strength of the axial ligand, qualitatively similar to the trend observed from the RDE-CA measurements (Figure 5a).

Note that there rising region in the RDEV and RDE-CA measurements in Figure 4 after the plateau at potentials $<-1.25 \mathrm{~V}$ is attributed to the onset of competitive HER from the EPG electrode, which occurs at $\sim-1.3 \mathrm{~V}$ vs SCE (Figure S12). $\mathrm{CPE}$ experiments conducted at $-1.35 \mathrm{~V}$ for $\mathrm{CoPc}, \mathrm{CoPc}(\mathrm{L} 3)$, and 
$\mathrm{CoPc}(\mathrm{L} 8)$ show a large increase in $\mathrm{H}_{2}$ production with $\mathrm{FE}_{\mathrm{H} 2} \geq 75 \%$, consistent with the postulated increase in the HER at these more negative potentials (Table S3).

\section{The Effect of $\sigma$-donor Strength of Axial Ligands on Electronic Structure of $\operatorname{CoPc}(\mathrm{L})$}

To better understand the influence of the $\sigma$-donor strength of axially-coordinating ligands on the electronic structure of $\mathrm{CoPc}(\mathrm{L})$, density functional theory (DFT) was used to examine molecular orbitals for the various $\operatorname{CoPc}(\mathrm{L})$ complexes. The orbitals with primarily $\mathrm{dz}^{2}$ character $\left(\mathrm{dz}^{2}-\mathrm{MOs}\right)$ and the highest occupied molecular orbitals (HOMOs) for $\mathrm{CoPc}$ and $\mathrm{CoPc}(\mathrm{L})$ are shown in Figure 6 for $\mathrm{CoPc}, \mathrm{CoPc}(\mathrm{L} 1)$, and $\mathrm{CoPc}(\mathrm{L} 8)$, and for all complexes in Figure S13. For all $\mathrm{CoPc}$ and $\mathrm{CoPc}(\mathrm{L})$ complexes, the HOMOs are primarily composed of $\pi$-orbitals of the Pc rings. The $\mathrm{dz}^{2}$ orbital of CoPc is relatively low energy (i.e. the HOMO -5 orbital), but upon axial ligation it increases in energy by $\sim 2.1 \mathrm{eV}$ and becomes the HOMO-1

for $\operatorname{CoPc}(\mathrm{L})$. The relative increase of the $\mathrm{dz}^{2}$ orbital energy increases with increasing $\sigma$-donor strength of $\mathrm{L}$ as shown in Figure 7a and summarized in Table S4. 

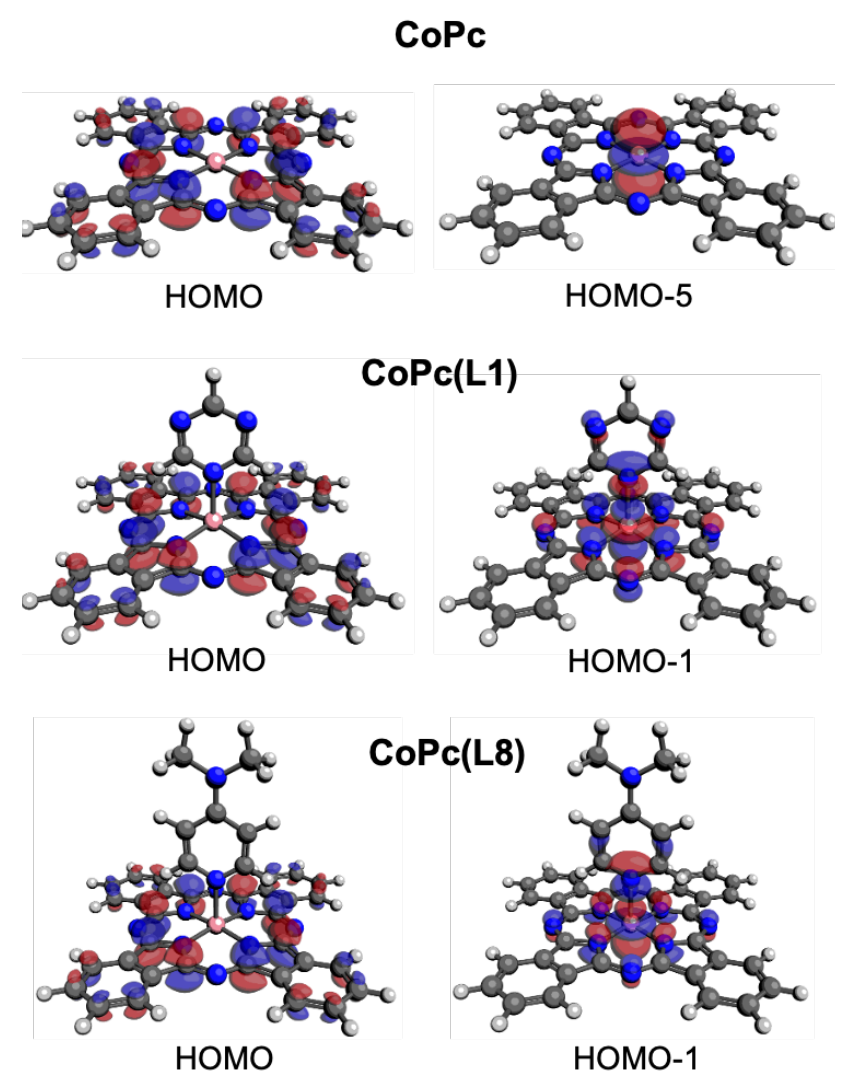

Figure 6. Graphical representations of the HOMO (left) and $\mathrm{dz}^{2}$ orbitals (right) for CoPc, $\mathrm{CoPc}(\mathrm{L} 1)$, and $\mathrm{CoPc}(\mathrm{L} 8)$. Calculated charge distributions (red and blue shaded orbitals) are based on DFT calculations (pink ball $=\mathrm{Co}$, blue ball $=\mathrm{N}$, grey ball $=\mathrm{C}$, white ball $=\mathrm{H}$ ). Isovalue is 0.10 a.u. 

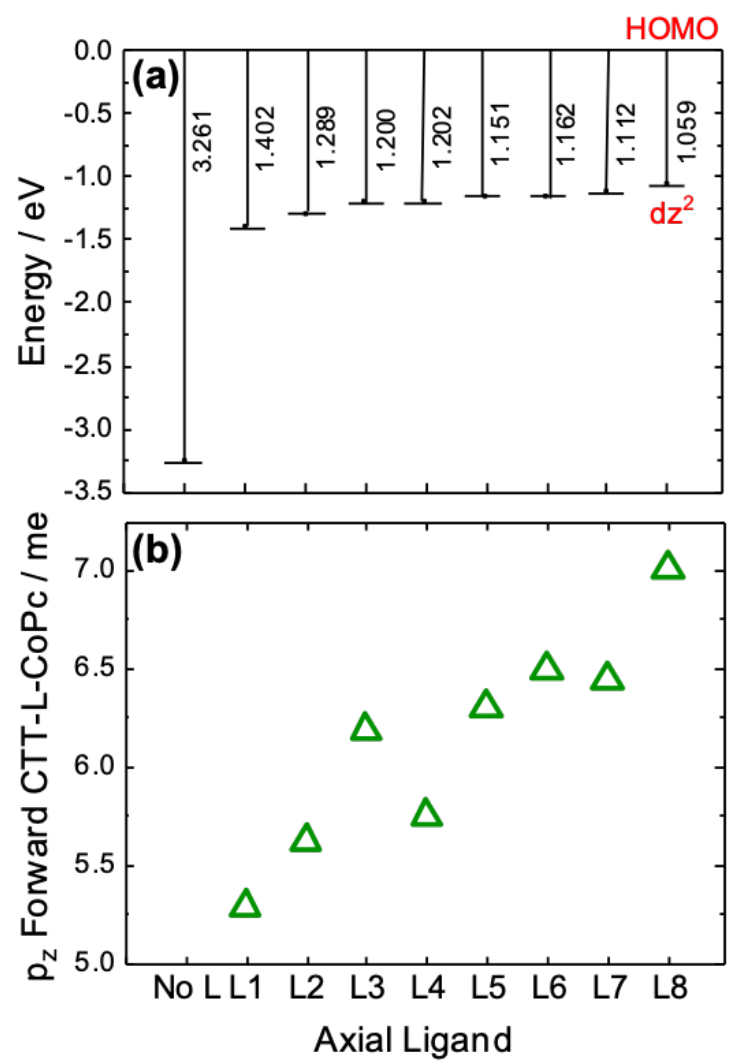

Figure 7. (a) Calculated energy differences between the HOMO and $d z^{2}-\mathrm{MO}$ for $\mathrm{CoPc}(\mathrm{L})$ with various axial ligands L. (b) The forward charge transfer term from the ligand L nitrogen $\mathrm{p}_{\mathrm{z}}$ to the CoPc complex (CTT-L-CoPc) from ALMO-CTA. CTT-L-CoPc are in millielectrons (me).

Charge transfer analysis (see computational details) determined the primary interaction between the CoPc complex and axial ligand $\mathrm{L}$ in $\mathrm{CoPc}(\mathrm{L})$ is $\sigma$-donation from the $\mathrm{p}_{z}$ orbital of the coordinating $\mathrm{N}$ atom to the $\mathrm{dz}^{2}$ orbital of the Co atom. This interaction between $\mathrm{N} \mathrm{p} \mathrm{p}_{\mathrm{z}}$ and Co $\mathrm{dz}^{2}$ accounts for $>80 \%$ of the forward charge transfer between the ligands L and the CoPc. The second significant interaction is a $\pi$ interaction between the $\mathrm{p}_{\mathrm{x}}$ orbitals of the conjugated $\mathrm{C}$ atoms in $\mathrm{L}$ and the $\mathrm{p}$ orbitals of the outer $\mathrm{C}-\mathrm{N}-\mathrm{C}$ atoms in the Pc, accounting for $\sim 10 \%$ of the forward charge transfer. The additional electron density on the Co center compared to the parent complex CoPc suggests that the Co will have increased 
nucleophilicity. Moreover, the magnitude of the forward charge transfer term from the ligand $\mathrm{L}$ to the CoPc complex (CTT-L-CoPc) increases with increasing $\sigma$-donor strength of $\mathrm{L}$ as shown in Figure $7 \mathrm{~b}$. The DFT findings are therefore consistent with the UV-Vis measurements showing a red shift in the Q-band as a function of $\sigma$-donor strength of L (Figure 3 and Figure S14). These results support the hypothesis that axial coordination increases the energy of the $\mathrm{Co} \mathrm{dz}^{2}$ orbital, and thus the nucleophilicity of the Co center, in proportion to the $\sigma$-donor strength of the axial ligand.

\section{Mechanistic Implications of Axial Coordination from First Principles Calculations}

The above DFT analysis focused on the electronic structure of the uncharged $\operatorname{CoPc}(\mathrm{L})$ species serves as a baseline for understanding the influence of axial coordination on the electronic structure. To best inform the electrocatalytic mechanism of the $\mathrm{CoPc}(\mathrm{L})$ system, it is important to understand the influence of axial coordination on the catalytically-active reduced $\mathrm{CoPc}$ and $\mathrm{CoPc}(\mathrm{L})$ species. Here, we introduce probable mechanisms for $\mathrm{CO}_{2} \mathrm{RR}$ by $\mathrm{CoPc}$ in order to identify relevant catalytically active species for further computational study.

Although the mechanism for the $\mathrm{CO}_{2} \mathrm{RR}$ by $\mathrm{CoPc}$ is likely condition-dependent and remains an active point of discussion, ${ }^{21,22,25,39}$ two mechanisms have emerged that are largely consistent with experimental measurements in aqueous solution and are depicted in Scheme 1. In Mechanism 1 (Scheme 1a), the active species for $\mathrm{CO}_{2}$ activation is the singly-reduced $[\mathrm{CoPc}]^{-}$intermediate, which can either coordinate and reduce $\mathrm{CO}_{2}$ to generate $\mathrm{CO}$ in the $\mathrm{CO}_{2} \mathrm{RR}$ pathway or undergo reductive protonation to generate $\mathrm{H}_{2}$ along the competitive HER pathway. In Mechanism 2 (Scheme 1b), CoPc is reduced by $2 \mathrm{e}^{-}$and protonated once (presumably on the Pc ring) to form $[\mathrm{CoPcH}]^{-}$. This species is the selectivity-determining intermediate that can either react with another $\mathrm{H}^{+}$to form $\mathrm{H}_{2}$ in an $\mathrm{HER}$ pathway or react with $\mathrm{CO}_{2}$ to form the $\mathrm{CO}_{2}$ adduct $\left[\mathrm{CoPcH}-\mathrm{CO}_{2}\right]^{-}$. The latter intermediate undergoes a putative intramolecular $\mathrm{H}^{+}$transfer from the 
Pc ring to the $\mathrm{CO}_{2}$ adduct followed by a subsequent solution protonation step to eventually generate $\mathrm{CO}$. Both mechanisms are consistent with KIE studies that show axial coordination changes the rate determining step from the initial $\mathrm{CO}_{2}$-coordination event (step i) for $\mathrm{CoPc}$ to a subsequent protonation event (step ii) for $\operatorname{CoPc}(\mathrm{L}) .^{18}$

\section{(a) Mechanism 1}

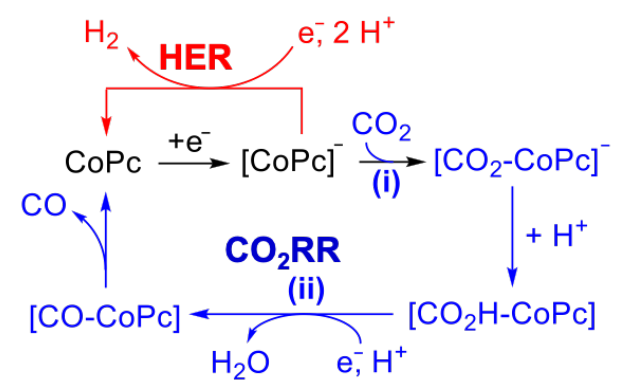

(b) Mechanism 2

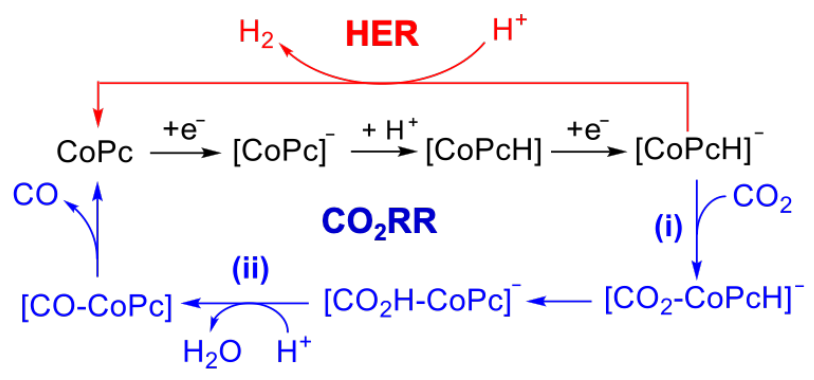

Scheme 1. Two proposed mechanisms for the $\mathrm{CO}_{2} \mathrm{RR}$ by CoPc. (a) In Mechanism $1, \mathrm{CO}_{2}$ coordination occurs at the singly-reduced catalyst. ${ }^{25,39}$ (b) In Mechanism 2, $\mathrm{CO}_{2}$ coordination occurs at the doubly-reduced and singly-protonated catalyst. ${ }^{15,21,22}$ Both mechanisms are consistent with KIE studies that show a change in the rate-determining step upon axial coordination from $\mathrm{CO}_{2}$ coordination (step i) to a subsequent protonation event (step ii). ${ }^{18}$ Postulated pathways for competitive HER are shown in red for each mechanism. 
To help distinguish between the two proposed mechanisms for $\mathrm{CO}_{2} \mathrm{RR}$ by $\mathrm{CoPc}(\mathrm{L})$ catalysts, we compared the experimental activity measurements to computed frontier orbitals, $\mathrm{CO}_{2}$ binding energies (BE), and charge transfer terms $(\mathrm{CTT})$ for the $\mathrm{CoPc}(\mathrm{L}) \mathrm{CO}_{2}$ adduct. We propose that a close correlation of increasing BE and CTT for the pertinent mechanistic intermediates in Mechanisms 1 or 2 with increasing $\sigma$-donor strength of the axial ligand suggests that the mechanism is consistent with experimental results (Figure 8). Such an agreement would then correlate $\mathrm{BE}$ and $\mathrm{CTT}$ of $\mathrm{CoPc}(\mathrm{L})$ to the $\mathrm{CO}_{2}$ adduct with the measured catalytic activity, which also increases with $\sigma$-donor strength of the axial ligand. These first-principles studies will relate the electronic properties of $\operatorname{CoPc}(\mathrm{L})$ to the measured electrocatalytic activity for the $\mathrm{CO}_{2} \mathrm{RR}$.

The orbital ordering for the intermediates preceding $\mathrm{CO}_{2}$ coordination was examined for each mechanism, $[\mathrm{CoPc}(\mathrm{L})]^{-}$for Mechanism 1 and $[\mathrm{CoPcH}(\mathrm{L})]^{-}$for Mechanism 2 (Figure $9 \mathrm{a}, \mathrm{b}$ ). In the case of the singly-reduced [CoPc] $]^{-}$active species from Mechanism 1, the $\mathrm{dz}^{2}-\mathrm{MO}$ is HOMO-3 (Figure 9a). Upon axial coordination to reach $[\mathrm{CoPc}(\mathrm{L})]^{-}$, the $\mathrm{dz}^{2}-\mathrm{MO}$ increases in energy to become the HOMO for all L1-L8 (Figure 9a, S16). This shows that the $\mathrm{dz}^{2}-\mathrm{MO}$ of $[\mathrm{CoPc}(\mathrm{L})]^{-}$is better poised to activate and coordinate the electrophilic $\mathrm{C}$ of $\mathrm{CO}_{2}$ compared to that of $[\mathrm{CoPc}]^{-}$, assuming Mechanism 1 is the operative mechanism for $\mathrm{CO}_{2} \mathrm{RR}$.

For the active species from Mechanism 2, $[\mathrm{CoPcH}]^{-}$, the $\mathrm{dz}^{2}-\mathrm{MO}$ is also a buried HOMO-3 similar to the intermediate in Mechanism 1 (Figure 9b). For the axially-coordinated $[\mathrm{CoPcH}(\mathrm{L})]^{-}$active species, the $\mathrm{dz}^{2}$-MO becomes HOMO-2 and the HOMO is still composed primarily of $\pi$-orbitals of the Pc rings (Figure $9 b, \mathrm{~S} 18)$. These calculations suggest that $\mathrm{Co}$ center of $[\mathrm{CoPcH}(\mathrm{L})]^{-}$is more nucleophilic than that of $[\mathrm{CoPcH}]^{-}$, but that the buried $\mathrm{dz}^{2}-\mathrm{MO}$ of $[\mathrm{CoPcH}(\mathrm{L})]^{-}$is not as well positioned energetically to interact with $\mathrm{CO}_{2}$ compared to the singly-reduced $[\mathrm{CoPc}(\mathrm{L})]^{-}$in Mechanism 1. This may suggest that Mechanism 2 is a less likely mechanism for the $\mathrm{CO}_{2} \mathrm{RR}$ compared to Mechanism 1. 


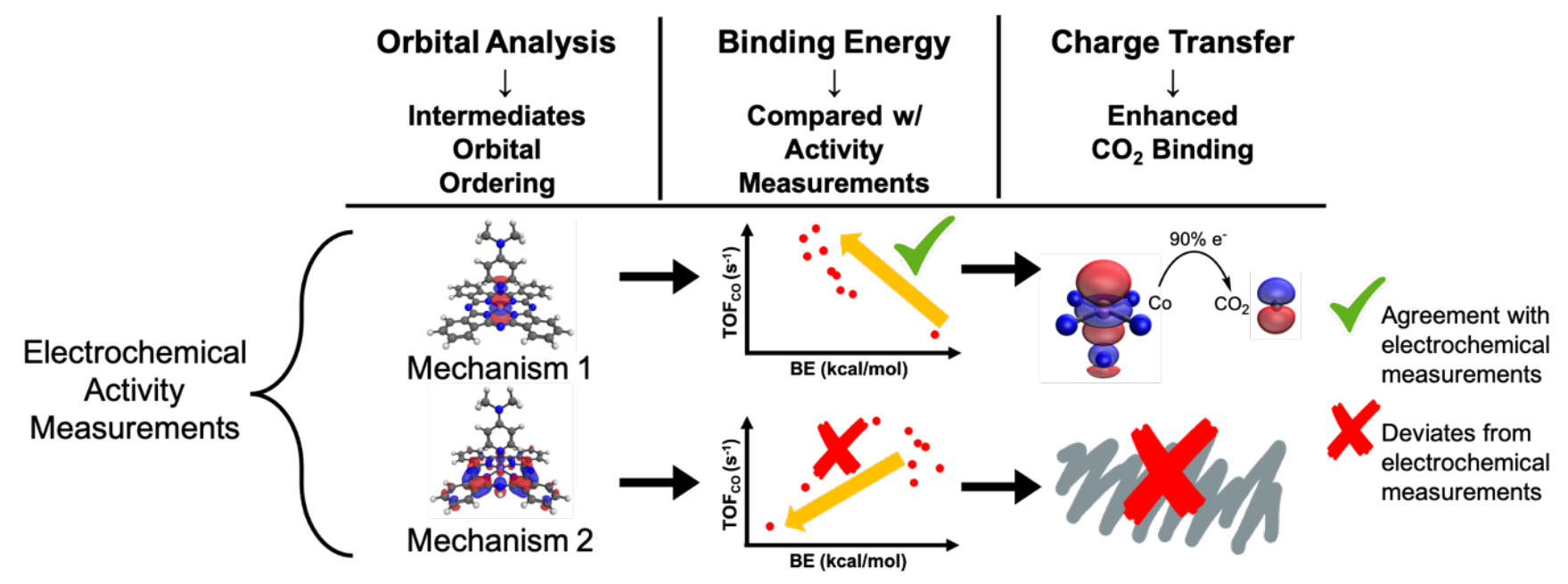

Figure 8. Overview of DFT analysis for the proposed $\mathrm{CO}_{2} \mathrm{RR}$ mechanisms for $\mathrm{CoPc}(\mathrm{L})$ catalysts. These calculations were used to look for trends that can explain the comparative measured electrocatalytic activities for the $\mathrm{CoPc}(\mathrm{L})$ systems. First, we determined the HOMO orbital character for the postulated catalytically-active intermediates. Next, we compared trends in the $\mathrm{CO}_{2}$ binding energy for the intermediates in Mechanism 1 and 2 to trends in the measured catalytic activities (TOF $\mathrm{CO}$ ). Finally, we measured the influence of the $\sigma$-donor strength of the axial ligands $\mathrm{L}$ on the extent of charge transfer between $\mathrm{CoPc}(\mathrm{L})$ and the $\mathrm{CO}_{2}$ adducts in the relevant intermediates for both mechanisms. If we assume that $\mathrm{CO}_{2}$-binding thermodynamically-controls $\mathrm{CO}_{2} \mathrm{RR}$ activity and the energy of the mechanisticallypertinent $\mathrm{CoPc}(\mathrm{L})-\mathrm{CO}_{2}$ intermediates influence catalytic turnover, then these analyses are more consistent with Mechanism 1 being the operative mechanism for $\mathrm{CO}_{2} \mathrm{RR}$ under our experimental conditions. 

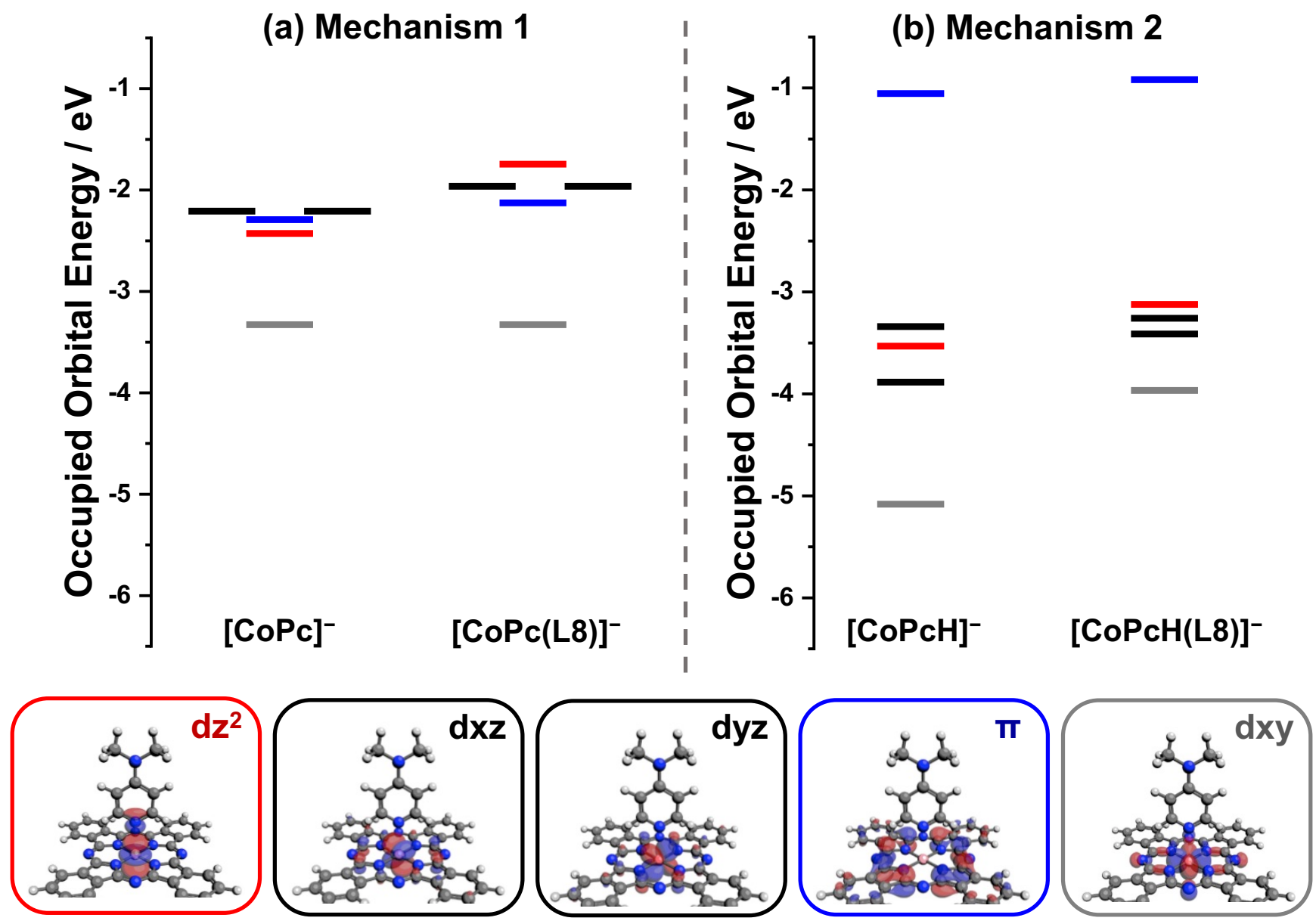

Figure 9. Energies of the occupied frontier molecular orbitals obtained for the singlet state singly reduced $[\mathrm{CoPc}(\mathrm{L})]^{-}$and the doublet state of the doubly reduced, singly protonated $[\mathrm{CoPcH}(\mathrm{L})]^{-}$with and without axially coordinating L ligands. The colors of the energy levels correspond to the specific molecular orbitals: red is $\mathrm{dz}^{2}$, black is $\mathrm{dxz}$ and dyz, grey is $\mathrm{dxy}$, and blue is the $\pi$ orbital of the Pc ring. Graphical representations of the molecular orbitals for $[\mathrm{CoPc}(\mathrm{L} 8)]^{-}$with color-coordinated labels are shown for reference, and the graphical representations for the other orbitals are shown in Figures S15 and S17. Summaries of the orbital energies and assignments are listed in Table S5 and Table S6. 
The $\mathrm{CO}_{2}$ coordination via the $\left[\mathrm{CoPc}(\mathrm{L})-\mathrm{CO}_{2}\right]^{-}$and $\left[\mathrm{CoPc}(\mathrm{L})-\mathrm{CO}_{2} \mathrm{H}\right]^{-}$intermediates were then evaluated based on the assumption that these intermediates are the thermodynamically controlling species prior to the rate-limiting $\mathrm{CO}_{2}$ conversion steps. According to Mechanism $1, \mathrm{CO}_{2}$ coordination should occur at the singly-reduced $[\mathrm{CoPc}(\mathrm{L})]^{-}$. The computed $\mathrm{BE}$ of $\mathrm{CO}_{2}$ in $\left[\mathrm{CoPc}(\mathrm{L})-\mathrm{CO}_{2}\right]^{-}$is much more negative (larger magnitude) than that of the comparable $\mathrm{CO}_{2}$-adduct of the four-coordinate CoPc species in $\left[\mathrm{CoPc}-\mathrm{CO}_{2}\right]^{-}$. This suggests that axial coordination facilitates the binding of $\mathrm{CO}_{2}$ at the singly-reduced state in Mechanism 1. This is consistent with our experimental observations that show axial coordination changes the rate-determining step from $\mathrm{CO}_{2}$ coordination to a subsequent mechanistic step. ${ }^{18}$ Moreover, the $\mathrm{BE}$ of the $\mathrm{CO}_{2}$ adduct increases with $\sigma$-donor ability of $\mathrm{L}$ as measured by the red-shift in the Q-band for the $\mathrm{CoPc}(\mathrm{L})$ complex (Figure 11a). In addition, there is a direct correlation between $\mathrm{BE}$ and $\mathrm{TOF}_{\mathrm{CO}}$ for the $\operatorname{CoPc}(\mathrm{L})$ complexes (Figure 11c). The DFT and experimental observations suggest that axial coordination by strong $\sigma$-donor ligands facilitates $\mathrm{CO}_{2}$ coordination, increasing the rate of $\mathrm{CO}_{2}$ reduction to $\mathrm{CO}$ by the $\operatorname{CoPc}(\mathrm{L})$ complexes.

According to Mechanism 2, $\mathrm{CO}_{2}$ coordination should occur at the doubly-reduced singly-protonated $[\mathrm{CoPcH}(\mathrm{L})]^{-}$, producing $\left[\mathrm{CoPc}(\mathrm{L})-\mathrm{CO}_{2} \mathrm{H}\right]^{-}$. However, unlike with Mechanism 1, there is no clear correlation between the $\mathrm{BE}$ of the $\mathrm{CO}_{2}$ adduct in the intermediate $\left[\mathrm{CoPc}(\mathrm{L})-\mathrm{CO}_{2} \mathrm{H}\right]^{-}$with either the $\sigma$ -

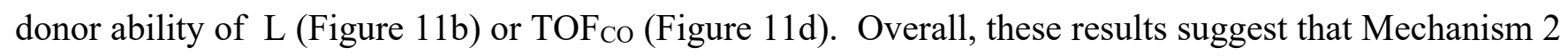
is less likely than Mechanism 1 to be operative under our experimental conditions.

To provide further understanding of the observed trends in BE, the extent of CTTs from the reduced $\mathrm{CoPc}(\mathrm{L})$ species to the $\mathrm{CO}_{2}$ adducts were computed. In the case of Mechanism 1, the primary interaction contributing to the charge transfer between the complex and $\mathrm{CO}_{2}$ is the $\sigma$-donation from the $\mathrm{Co} \mathrm{dz}^{2}$ to the $\mathrm{p}_{\mathrm{z}}$ orbitals in the $\mathrm{CO}_{2}$ adduct (Table S7). For the intermediate $\left[\mathrm{CoPc}(\mathrm{L})-\mathrm{CO}_{2}\right]^{-}$, there is a general increase in CTT between $[\mathrm{CoPc}(\mathrm{L})]^{-}$and $\mathrm{CO}_{2}$ with increasing $\sigma$-donor strength of the ligand $\mathrm{L}$ (Figure 12a), and 
this increased CTT is correlated to the increased activity for the $\mathrm{CO}_{2} \mathrm{RR}$ (Figure 12b). The extent of CTT for the $[\mathrm{CoPc}(\mathrm{L})]^{-}$species to the protonated $\mathrm{CO}_{2}$ adducts for $\left[\mathrm{CoPc}(\mathrm{L})-\mathrm{CO}_{2} \mathrm{H}\right]^{-}$was calculated for Mechanism 2 (Table S8), but there was a lack of correlation between the CTT and the experimentallymeasured activity (Figure S21). The trends in CTT to $\mathrm{CO}_{2}$ with $\mathrm{L}$ were less predictive of electrocatalytic activity for the key intermediate of Mechanism 2 compared to Mechanism 1. 

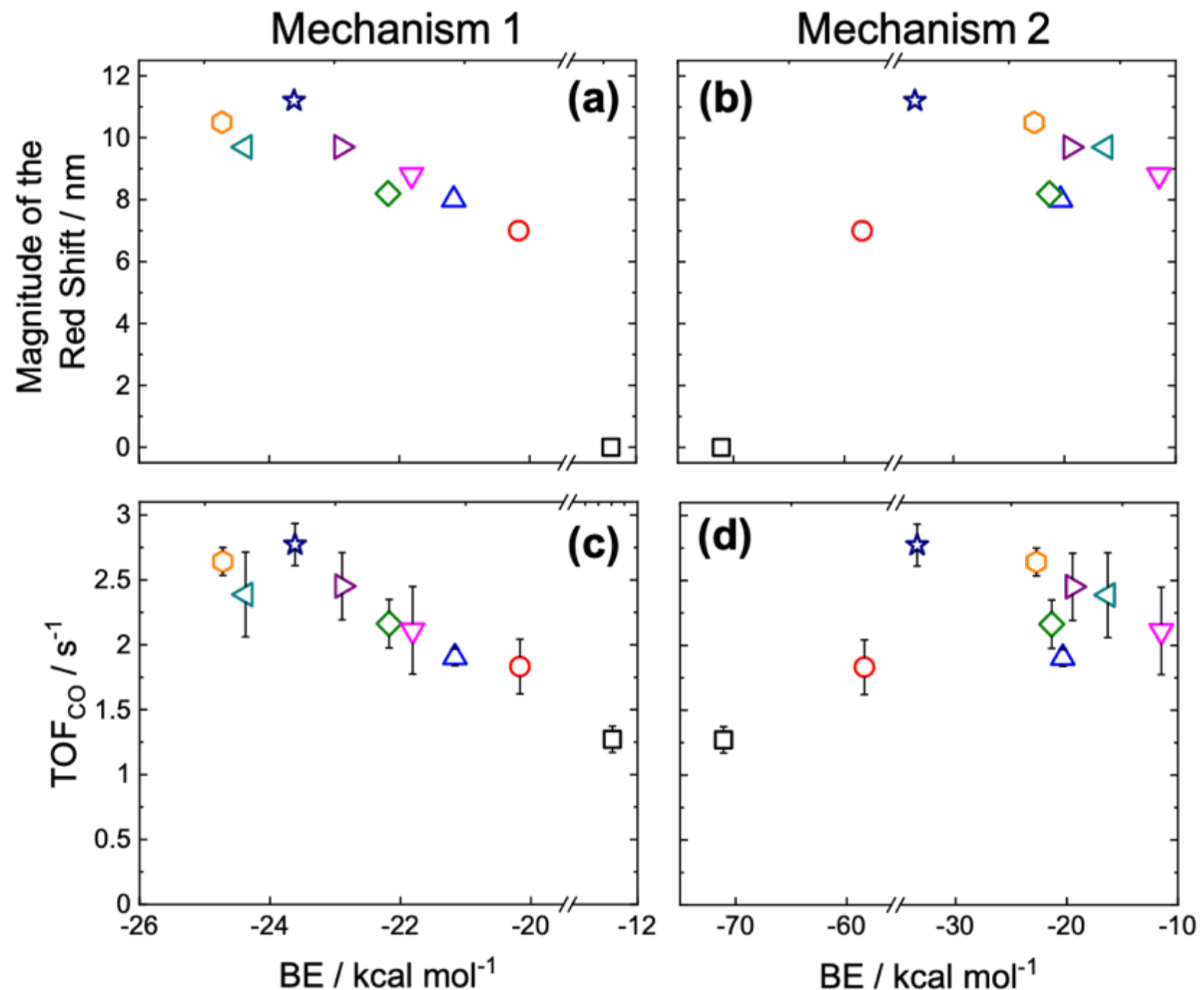

\section{$\square \operatorname{CoPc} \bigcirc \operatorname{CoPc}(\mathrm{L} 1) \triangle \operatorname{CoPc}(\mathrm{L} 2) \diamond \operatorname{CoPc}(\mathrm{L} 3) \nabla \operatorname{CoPc}(\mathrm{L} 4)$ $\triangleleft \operatorname{CoPc}(\mathrm{L} 5) \quad \triangleright \operatorname{CoPc}(\mathrm{L6}) \quad \triangleright \operatorname{CoPc}(\mathrm{L} 7) \quad \& \operatorname{CoPc}(\mathrm{L} 8)$}

Figure 11. (a) The magnitude of the red shift in $\lambda_{\max }$ of the Q-band for the $\mathrm{CoPc}(\mathrm{L})$ complex (related to the $\sigma$-donor ability of $\mathrm{L})$ is plotted versus the binding energy $(\mathrm{BE})$ of $\mathrm{CO}_{2}$ adduct in the $\left[\mathrm{CoPc}(\mathrm{L})-\mathrm{CO}_{2}\right]^{-}$ intermediate. b) The magnitude of the red shift in $\lambda_{\max }$ versus $\mathrm{BE}$ of the $\mathrm{CO}_{2} \mathrm{H}$ adduct in $[\mathrm{CoPc}(\mathrm{L})-$ $\left.\mathrm{CO}_{2} \mathrm{H}\right]^{-}$. (c-d) Same as (a) and (b), respectively, but with y-axis as Turnover Frequency for $\mathrm{CO}$ $\left(\mathrm{TOF}_{\mathrm{CO}}\right)$. $\mathrm{TOF}_{\mathrm{CO}}$ measurements here were determined by multiplying the RDE-CA measurements at $-1.25 \mathrm{~V}$ vs SCE by the $\mathrm{FE}_{\mathrm{CO}}$ from the CPE measurements at $-1.25 \mathrm{~V}$. Graphical representations for the HOMOs and orbitals showing the interaction between the complex and $\mathrm{CO}_{2}$ for $\left[\mathrm{CoPc}(\mathrm{L})-\mathrm{CO}_{2}\right]^{-}$ and $\left[\mathrm{CoPc}(\mathrm{L})-\mathrm{CO}_{2} \mathrm{H}\right]^{-}$are shown in Figures $\mathrm{S} 19$ and S20, respectively. 


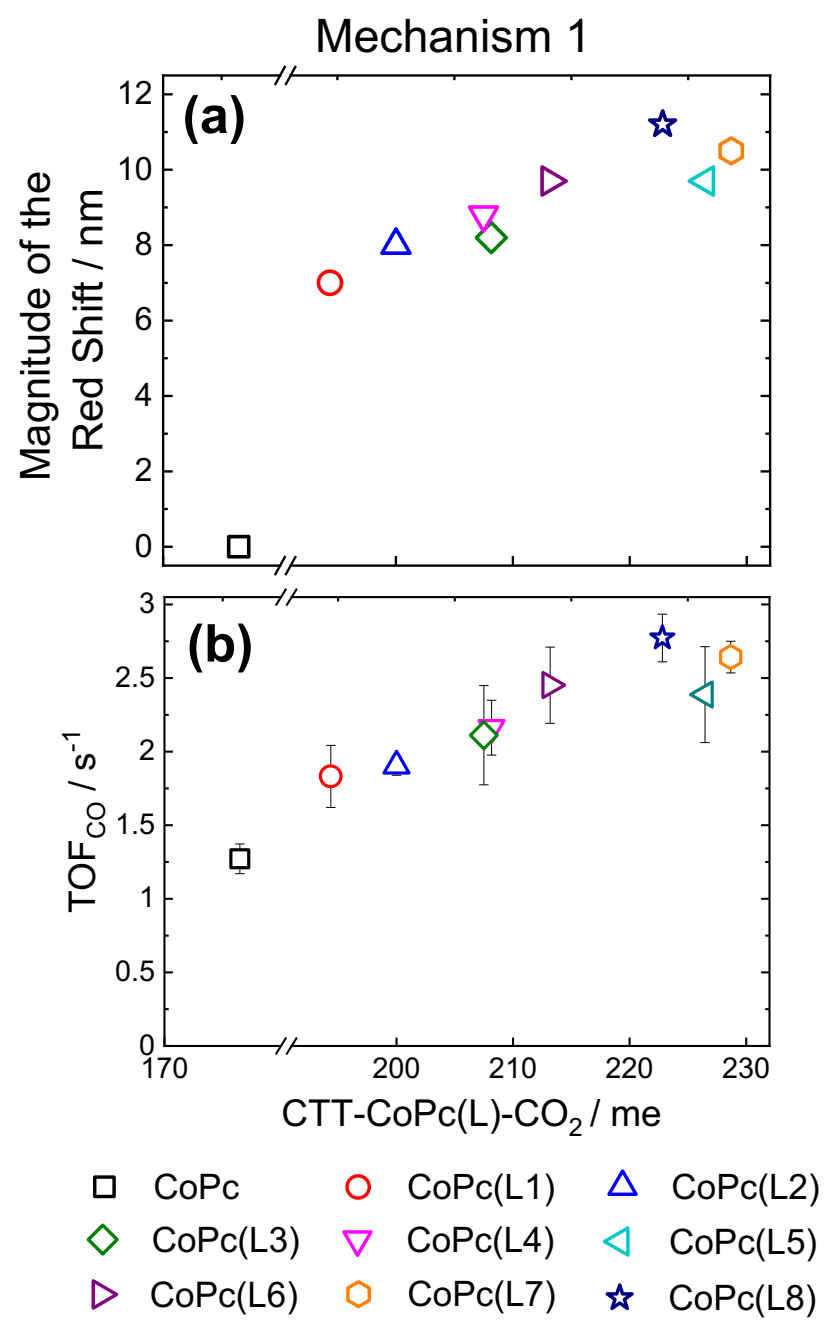

Figure 12. (a) The magnitude of the red shift in $\lambda_{\max }$ of the Q-band plotted versus the forward charge transfer term from the singly-reduced $\mathrm{CoPc}(\mathrm{L})$ to the coordinated $\mathrm{CO}_{2}$ adduct in the $\left[\mathrm{CoPc}(\mathrm{L})-\mathrm{CO}_{2}\right]^{-}$ intermediates $\left(\mathrm{CTT}-\mathrm{CoPc}(\mathrm{L})-\mathrm{CO}_{2}\right)(\mathrm{b})$ The activity as measured by the Turnover Frequency $\left(\mathrm{TOF}_{\mathrm{CO}}\right)$ for the $\mathrm{CoPc}(\mathrm{L})$ complexes is plotted versus the same CTT. CTT were from ALMO-CTA analysis, and

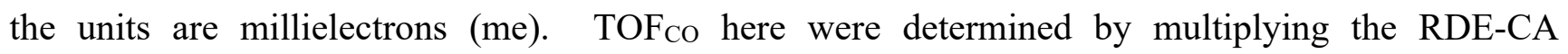
measurements at $-1.25 \mathrm{~V}$ vs SCE by the $\mathrm{FE}_{\mathrm{CO}}$ from the CPE measurements at $-1.25 \mathrm{~V}$. 


\section{CONCLUSIONS}

It has been previously shown that axial ligation of the CoPc complex by either a coordination ligand such as pyridine (L3) or a coordinating polymer such as P4VP results in increased activity and selectivity for the $\mathrm{CO}_{2} \mathrm{RR}$ to $\mathrm{CO}$ in aqueous phosphate solutions. ${ }^{17,18,21,22}$ We hypothesized that axial coordination increases the energy of the $\mathrm{dz}^{2}$ orbital, the orbital most likely involved in $\mathrm{CO}_{2}$ coordination, and that this higher energy $\mathrm{dz}^{2}$ orbital facilitates $\mathrm{CO}_{2}$ reduction. The combined electrochemical and computational study reported here provides strong support for this hypothesis. We investigated the activity for the $\mathrm{CO}_{2} \mathrm{RR}$ by a series of $\mathrm{CoPc}(\mathrm{L})$ complexes, where $\mathrm{L}$ increases in $\sigma$-donor strength from the relatively weak $\sigma$-donor triazine (L1) to the comparatively strong sigma donor 4-dimethylaminopyridine (L8). Our studies showed a correlation between the increasing $\sigma$-donor strength of $L$ and the increased catalytic activity of the resulting $\operatorname{CoPc}(\mathrm{L})$ complexes for the $\mathrm{CO}_{2} \mathrm{RR}$. Using DFT analysis, we also showed that the relative energy of the $\mathrm{dz}^{2}$ orbital increases with increasing $\sigma$-donor ability of the axial ligand, and that Co $\mathrm{dz}^{2}$ orbital is the primary orbital that interacts with $\mathrm{CO}_{2}$ in the reduced $\mathrm{CoPc}(\mathrm{L})-\mathrm{CO}_{2}$ intermediates. These findings suggest that the observed increases in $\mathrm{CO}_{2} \mathrm{RR}$ activity for $\mathrm{CoPc}(\mathrm{L})$ with increasing $\sigma$-donor ability of $\mathrm{L}$ are correlated with the increased relative energy of the $\mathrm{Co} \mathrm{dz}^{2}$ orbitals in the $\mathrm{CoPc}(\mathrm{L})$ complexes.

We also compared first-principles calculations of $\mathrm{CO}_{2}$ Binding Energy (BE) and Charge Transfer terms (CTT) between the $\mathrm{CoPc}(\mathrm{L})$ and $\mathrm{CO}_{2}$ for active intermediates in two proposed mechanisms for the $\mathrm{CO}_{2} \mathrm{RR}$ by CoPc. We showed that, in the case of Mechanism 1, where $\mathrm{CO}_{2}$ binding occurs after the first reduction of the $\mathrm{CoPc}(\mathrm{L})$ system, the $\mathrm{CTT}$ and $\mathrm{BE}$ terms for the singly-reduced $\left[\mathrm{CoPc}(\mathrm{L})-\mathrm{CO}_{2}\right]^{-}$ intermediate increased with increasing $\sigma$-donor ability of the ligand. The result is a direct correlation of the calculated CTT and BE terms with the experimentally measured $\mathrm{CO}_{2} \mathrm{RR}$ activity, suggesting that Mechanism 1 is a possible operative mechanism for this reaction. However, for Mechanism 2, where $\mathrm{CO}_{2}$ binding occurs after the second reduction and first protonation of the $\operatorname{CoPc}(\mathrm{L})$ system, there was a less 
clear correlation between the calculated CTT and BE terms for the doubly-reduced, singly protonated $\left[\mathrm{CoPc}(\mathrm{L})-\mathrm{CO}_{2} \mathrm{H}\right]^{-}$intermediate and the $\sigma$-donor ability of the ligand. Consequently, there was no clear correlation between the BE and CTT terms for Mechanism 2 and the measured catalytic activity, suggesting that Mechanism 2 is less likely to be an operative mechanism. From these studies, we conclude that Mechanism 1 is more likely than Mechanism 2 to explain the $\mathrm{CO}_{2} \mathrm{RR}$ by the $\mathrm{CoPc}$ and $\mathrm{CoPc}(\mathrm{L})$ systems under our experimental conditions.

Overall, our studies provide strong support that axial ligation increases the energy of the $\mathrm{dz}^{2}$ orbital in the $\operatorname{CoPc}(\mathrm{L})$ complexes, the extent of this increase in the $\mathrm{dz}^{2}$ orbital energy is dependent on the $\sigma$-donor strength of the axial ligand, and that this increased $\mathrm{dz}^{2}$ orbital energy for the $\operatorname{CoPc}(\mathrm{L})$ complexes is likely correlated to the observed increase in activity for the $\mathrm{CO}_{2} \mathrm{RR}$. We believe that these studies illustrating the influence of axial coordination on electronic structure and electrocatalytic activity provide important design considerations for future macrocyclic $\mathrm{MN}_{4}$-based electrocatalytic systems.

\section{ACKNOWLEDGEMENTS}

We thank Weijie Feng, Matthew D. Hannigan, and Alan E. Rask for useful discussions regarding computational studies. This work was supported by an NSF-CAREER grant (CHE-1751791). Y. L. was partially supported by a Rackham One-Term Dissertation Fellowship from the University of Michigan. K. E. R. C. was partially supported by a GEM Full Fellowship from the National GEM Consortium. T. L. S. was partially supported by the National Science Foundation Graduate Research Fellowship Program (DGE 1256260).

\section{ASSOCIATED CONTENT}

Supporting Information. The Supporting Information is available free of charge. 
- UV-Vis spectra; represtentaitve rotating disk voltammograms and rotating disk chronomamperometric steps; summary of results from controlled-potential electrolysis experiments; calculated highest occupied molecular orbitals, $\mathrm{dz}^{2}$ orbitals, and other relevant molecular orbitals for $\mathrm{CoPc}$ and $\mathrm{CoPc}(\mathrm{L})$ species.

- The $X Y Z$ coordinates of the structures used in the DFT calculations for all species investigated: $\mathrm{CoPc}, \mathrm{CoPc}(\mathrm{L}),[\mathrm{CoPc}]^{-},[\mathrm{CoPc}(\mathrm{L})]^{-},\left[\mathrm{CoPc}-\mathrm{CO}_{2}\right]^{-},\left[\mathrm{CoPc}(\mathrm{L})-\mathrm{CO}_{2}\right]^{-},[\mathrm{CoPcH}]^{-},[\mathrm{CoPcH}(\mathrm{L})]^{-}$ $\left[\mathrm{CoPc}-\mathrm{CO}_{2} \mathrm{H}\right]^{-}$and $\left[\mathrm{CoPc}(\mathrm{L})-\mathrm{CO}_{2} \mathrm{H}\right]^{-} ; \mathrm{L}=\mathrm{L} 1$ to $\mathrm{L} 8$.

\section{AUTHOR INFORMATION}

\section{Author Information:}

*Email for P. M. Z.: paulzim@umich.edu

*Email for C. C. L. M.: cmccrory@umich.edu

\section{Author Contributions:}

${ }^{\#}$ K.E.R.C. and Y.L. contributed equally to this work.

\section{ORCID}

Kevin E. Rivera Cruz: 0000-0001-6690-1571

Yingshuo Liu: 0000-0003-4780-8384

Taylor L. Soucy: 0000-0002-0090-6721

Paul M. Zimmerman: 0000-0002-7444-1314

Charles C. L. McCrory: 0000-0001-9039-7192

Notes:

The authors declare no competiting financial interest. 


\section{REFERENCES}

(1) Roy, S. C.; Varghese, O. K.; Paulose, M.; Grimes, C. A. "Toward Solar Fuels: Photocatalytic Conversion of Carbon Dioxide to Hydrocarbons," ACS Nano 2010, 4, 1259-1278. http://dx.doi.org/10.1021/nn9015423

(2) Whipple, D. T.; Kenis, P. J. A. "Prospects of $\mathrm{CO} 2$ Utilization via Direct Heterogeneous Electrochemical Reduction," J. Phys. Chem. Lett. 2010, 1, 3451-3458. http://dx.doi.org/10.1021/jz1012627

(3) Inglis, J. L.; MacLean, B. J.; Pryce, M. T.; Vos, J. G. "Electrocatalytic pathways towards sustainable fuel production from water and $\mathrm{CO}_{2}, "$ Coord. Chem. Rev. 2012, 256, 2571-2600. http://dx.doi.org/10.1016/j.ccr.2012.05.002

(4) Kondratenko, E. V.; Mul, G.; Baltrusaitis, J.; Larrazábal, G. O.; Pérez-Ramírez, J. "Status and perspectives of $\mathrm{CO} 2$ conversion into fuels and chemicals by catalytic, photocatalytic and electrocatalytic processes," Energy Environ. Sci. 2013, 6. http://dx.doi.org/10.1039/c3ee41272e

(5) Martín, A. J.; Larrazábal, G. O.; Pérez-Ramírez, J. "Towards sustainable fuels and chemicals through the electrochemical reduction of $\mathrm{CO} 2$ : lessons from water electrolysis," Green Chem. 2015, 17, 51145130. http://dx.doi.org/10.1039/C5GC01893E

(6) Shaner, M. R.; Atwater, H. A.; Lewis, N. S.; McFarland, E. W. "A comparative technoeconomic analysis of renewable hydrogen production using solar energy," Energy Environ. Sci. 2016, 9, 2354-2371. http://dx.doi.org/10.1039/C5EE02573G

(7) Nocera, D. G. "Solar Fuels and Solar Chemicals Industry," Acc. Chem. Res. 2017, 50, 616-619. http://dx.doi.org/10.1021/acs.accounts.6b00615 
(8) Senftle, T. P.; Carter, E. A. "The Holy Grail: Chemistry Enabling an Economically Viable $\mathrm{CO}_{2}$ Capture, Utilization, and Storage Strategy," Acc. Chem. Res. 2017, 50, 472-475. http://dx.doi.org/10.1021/acs.accounts.6b00479

(9) Spurgeon, J. M.; Kumar, B. "A comparative technoeconomic analysis of pathways for commercial electrochemical CO2 reduction to liquid products," Energy Environ. Sci. 2018, 11, 1536-1551. http://dx.doi.org/10.1039/C8EE00097B

(10) Mustafa, A.; Lougou, B. G.; Shuai, Y.; Wang, Z.; Tan, H. "Current technology development for CO2 utilization into solar fuels and chemicals: A review," J. Energy Chem. 2020, 49, 96-123. http://dx.doi.org/10.1016/j.jechem.2020.01.023

(11) Crabtree, R. H. "Alternate Strategies for Solar Fuels from Carbon Dioxide," ACS Energy Lett. 2020, 5, 2505-2507. http://dx.doi.org/10.1021/acsenergylett.0c01359

(12) Verma, S.; Kim, B.; Jhong, H.-R. M.; Ma, S.; Kenis, P. J. A. "A Gross-Margin Model for Defining Technoeconomic Benchmarks in the Electroreduction of CO2," ChemSusChem 2016, 9, 1972-1979. $\underline{\text { http://dx.doi.org/10.1002/cssc.201600394 }}$

(13) Zheng, T.; Jiang, K.; Wang, H. "Recent Advances in Electrochemical CO2-to-CO Conversion on Heterogeneous Catalysts," Adv. Mater. 2018, 30, 1802066. http://dx.doi.org/10.1002/adma.201802066

(14) De Luna, P.; Hahn, C.; Higgins, D.; Jaffer, S. A.; Jaramillo, T. F.; Sargent, E. H. "What would it take for renewably powered electrosynthesis to displace petrochemical processes?," Science 2019, 364, eaav3506. http://dx.doi.org/10.1126/science.aav3506

(15) Lieber, C. M.; Lewis, N. S. "Catalytic reduction of carbon dioxide at carbon electrodes modified with cobalt phthalocyanine," J. Am. Chem. Soc. 1984, 106, 5033-5034. http://dx.doi.org/10.1021/ja00329a082 
(16) Kapusta, S.; Hackerman, N. "Carbon Dioxide Reduction at a Metal Phthalocyanine Catalyzed Carbon Electrode," J. Electrochem. Soc. 1984, 131, 1511-1514. http://dx.doi.org/10.1149/1.2115882

(17) Kramer, W. W.; McCrory, C. C. L. "Polymer coordination promotes selective $\mathrm{CO}_{2}$ reduction by cobalt phthalocyanine," Chem. Sci. 2016, 7, 2506-2515. http://dx.doi.org/10.1039/C5SC04015A

(18) Liu, Y.; McCrory, C. C. L. "Modulating the mechanism of electrocatalytic $\mathrm{CO}_{2}$ reduction by cobalt phthalocyanine through polymer coordination and encapsulation," Nat. Commun. 2019, 10, 1683. http://dx.doi.org/10.1038/s41467-019-09626-8

(19) Liu, Y.; Deb, A.; Leung, K. Y.; Nie, W.; Dean, W. S.; Penner-Hahn, J. E.; McCrory, C. C. L. "Determining the coordination environment and electronic structure of polymer-encapsulated cobalt phthalocyanine under electrocatalytic $\mathrm{CO}_{2}$ reduction conditions using in situ X-Ray absorption spectroscopy," Dalton Trans. 2020, 49, 16329-16339. http://dx.doi.org/10.1039/D0DT01288B

(20) Kusuda, K.; Ishihara, R.; Yamaguchi, H.; Izumi, I. "Electrochemical investigation of thin films of cobalt phthalocyanine and cobalt- $4,4^{\prime}, 4^{\prime \prime}, 4^{\prime}$ ' -tetracarboxyphthalocyanine and the reduction of carbon monoxide, formic acid and formaldehyde mediated by the $\mathrm{Co}(\mathrm{I})$ complexes," Electrochim. Acta 1986, 31, 657-663. http://dx.doi.org/10.1016/0013-4686(86)87032-3

(21) Yoshida, T.; Kamato, K.; Tsukamoto, M.; Iida, T.; Schlettwein, D.; Wöhrle, D.; Kaneko, M. "Selective electroacatalysis for $\mathrm{CO}_{2}$ reduction in the aqueous phase using cobalt phthalocyanine/poly-4vinylpyridine modified electrodes," J. Electroanal. Chem. 1995, 385, 209-225. $\underline{\text { http://dx.doi.org/10.1016/0022-0728(94)03762-R }}$

(22) Abe, T.; Yoshida, T.; Tokita, S.; Taguchi, F.; Imaya, H.; Kaneko, M. "Factors affecting selective electrocatalytic $\mathrm{CO}_{2}$ reduction with cobalt phthalocyanine incorporated in a polyvinylpyridine membrane coated on a graphite electrode," J. Electroanal. Chem. 1996, 412, 125-132. http://dx.doi.org/10.1016/0022-0728(96)04631-1 
(23) Zhang, X.; Wu, Z.; Zhang, X.; Li, L.; Li, Y.; Xu, H.; Li, X.; Yu, X.; Zhang, Z.; Liang, Y.; Wang, H. "Highly selective and active $\mathrm{CO} 2$ reduction electrocatalysts based on cobalt phthalocyanine/carbon nanotube hybrid structures," Nat. Commun. 2017, 8, 14675. http://dx.doi.org/10.1038/ncomms14675

(24) Wu, H.; Zeng, M.; Zhu, X.; Tian, C.; Mei, B.; Song, Y.; Du, X.-L.; Jiang, Z.; He, L.; Xia, C.; Dai, S. "Defect Engineering in Polymeric Cobalt Phthalocyanine Networks for Enhanced Electrochemical CO2 Reduction," ChemElectroChem 2018, 5, 2717-2721. http://dx.doi.org/10.1002/celc.201800806

(25) Zhu, M.; Ye, R.; Jin, K.; Lazouski, N.; Manthiram, K. "Elucidating the Reactivity and Mechanism of $\mathrm{CO}_{2}$ Electroreduction at Highly Dispersed Cobalt Phthalocyanine," ACS Energy Lett. 2018, 3, 13811386. http://dx.doi.org/10.1021/acsenergylett.8b00519

(26) Boutin, E.; Wang, M.; Lin, J. C.; Mesnage, M.; Mendoza, D.; Lassalle-Kaiser, B.; Hahn, C.; Jaramillo, T. F.; Robert, M. "Aqueous Electrochemical Reduction of Carbon Dioxide and Carbon Monoxide into Methanol with Cobalt Phthalocyanine," Angew. Chem. Int. Ed. 2019, 58, 16172-16176. http://dx.doi.org/10.1002/anie.201909257

(27) Choi, J.; Wagner, P.; Gambhir, S.; Jalili, R.; MacFarlane, D. R.; Wallace, G. G.; Officer, D. L. "Steric Modification of a Cobalt Phthalocyanine/Graphene Catalyst To Give Enhanced and Stable Electrochemical $\mathrm{CO} 2$ Reduction to CO," ACS Energy Lett. 2019, 4, 666-672. http://dx.doi.org/10.1021/acsenergylett.8b02355

(28) Wang, M.; Torbensen, K.; Salvatore, D.; Ren, S.; Joulié, D.; Dumoulin, F.; Mendoza, D.; LassalleKaiser, B.; Işci, U.; Berlinguette, C. P.; Robert, M. " $\mathrm{CO}_{2}$ electrochemical catalytic reduction with a highly active cobalt phthalocyanine," Nat. Commun. 2019, 10, 3602. http://dx.doi.org/10.1038/s41467-019$\underline{11542-\mathrm{W}}$ 
(29) Zhu, M.; Chen, J.; Guo, R.; Xu, J.; Fang, X.; Han, Y.-F. "Cobalt phthalocyanine coordinated to pyridine-functionalized carbon nanotubes with enhanced $\mathrm{CO} 2$ electroreduction," Applied Catalysis B: Environmental 2019, 251, 112-118. http://dx.doi.org/10.1016/j.apcatb.2019.03.047

(30) Wu, Y.; Jiang, Z.; Lu, X.; Liang, Y.; Wang, H. "Domino electroreduction of $\mathrm{CO}_{2}$ to methanol on a molecular catalyst," Nature 2019, 575, 639-642. http://dx.doi.org/10.1038/s41586-019-1760-8

(31) Yang, Z.; Zhang, X.; Long, C.; Yan, S.; Shi, Y.; Han, J.; Zhang, J.; An, P.; Chang, L.; Tang, Z. "Covalently anchoring cobalt phthalocyanine on zeolitic imidazolate frameworks for efficient carbon dioxide electroreduction," CrystEngComm 2020, 22, 1619-1624. http://dx.doi.org/10.1039/C9CE01517E (32) Li, T.-T.; Mei, Y.; Li, H.; Qian, J.; Wu, M.; Zheng, Y.-Q. "Highly Selective and Active Electrochemical Reduction of $\mathrm{CO} 2$ to $\mathrm{CO}$ on a Polymeric Co(II) Phthalocyanine@Graphitic Carbon Nitride Nanosheet-Carbon Nanotube Composite," Inorg. $\quad$ Chem. 2020. http://dx.doi.org/10.1021/acs.inorgchem.0c01977

(33) Xia, Y.; Kashtanov, S.; Yu, P.; Chang, L.-Y.; Feng, K.; Zhong, J.; Guo, J.; Sun, X. "Identification of dual-active sites in cobalt phthalocyanine for electrochemical carbon dioxide reduction," Nano Energy 2020, 67, 104163. http://dx.doi.org/10.1016/j.nanoen.2019.104163

(34) Wang, X.; Cai, Z.-F.; Wang, Y.-Q.; Feng, Y.-C.; Yan, H.-J.; Wang, D.; Wan, L.-J. "In Situ Scanning Tunneling Microscopy of Cobalt-Phthalocyanine-Catalyzed CO2 Reduction Reaction," Angew. Chem. Int. Ed. 2020, 59, 16098-16103. http://dx.doi.org/10.1002/anie.202005242

(35) Wu, Y.; Hu, G.; Rooney, C. L.; Brudvig, G. W.; Wang, H. "Heterogeneous Nature of Electrocatalytic CO/CO2 Reduction by Cobalt Phthalocyanines," ChemSusChem 2020, n/a. $\underline{\text { http://dx.doi.org/10.1002/cssc.202001396 }}$ 
(36) Huai, M.; Yin, Z.; Wei, F.; Wang, G.; Xiao, L.; Lu, J.; Zhuang, L. "Electrochemical $\mathrm{CO}_{2}$ reduction on heterogeneous cobalt phthalocyanine catalysts with different carbon supports," Chem. Phys. Lett. 2020, 754, 137655. http://dx.doi.org/10.1016/j.cplett.2020.137655

(37) Zeng, J. S.; Corbin, N.; Williams, K.; Manthiram, K. "Kinetic Analysis on the Role of Bicarbonate in Carbon Dioxide Electroreduction at Immobilized Cobalt Phthalocyanine," ACS Catal. 2020, 10, 43264336. http://dx.doi.org/10.1021/acscatal.9b05272

(38) De Riccardis, A.; Lee, M.; Kazantsev, R. V.; Garza, A. J.; Zeng, G.; Larson, D. M.; Clark, E. L.; Lobaccaro, P.; Burroughs, P. W. W.; Bloise, E.; Ager, J. W.; Bell, A. T.; Head-Gordon, M.; Mele, G.; Toma, F. M. "Heterogenized Pyridine-Substituted Cobalt(II) Phthalocyanine Yields Reduction of CO2 by Tuning the Electron Affinity of the Co Center," ACS Appl. Mater. Interfaces 2020, 12, 5251-5258. http://dx.doi.org/10.1021/acsami.9b18924

(39) Han, N.; Wang, Y.; Ma, L.; Wen, J.; Li, J.; Zheng, H.; Nie, K.; Wang, X.; Zhao, F.; Li, Y.; Fan, J.; Zhong, J.; Wu, T.; Miller, D. J.; Lu, J.; Lee, S.-T.; Li, Y. "Supported Cobalt Polyphthalocyanine for HighPerformance Electrocatalytic $\mathrm{CO}_{2} \quad$ Reduction," Chem 2017, 3, 652-664. http://dx.doi.org/10.1016/j.chempr.2017.08.002

(40) Lin, L.; Li, H.; Yan, C.; Li, H.; Si, R.; Li, M.; Xiao, J.; Wang, G.; Bao, X. "Synergistic Catalysis over Iron-Nitrogen Sites Anchored with Cobalt Phthalocyanine for Efficient CO2 Electroreduction," Adv Mater 2019, 31, e1903470. http://dx.doi.org/10.1002/adma.201903470

(41) Lin, L.; Liu, T.; Xiao, J.; Li, H.; Wei, P.; Gao, D.; Nan, B.; Si, R.; Wang, G.; Bao, X. "Enhancing $\mathrm{CO} 2$ Electroreduction to Methane with a Cobalt Phthalocyanine and Zinc-Nitrogen-Carbon Tandem Catalyst," Angew Chem Int Ed Engl 2020, 59, 22408-22413. http://dx.doi.org/10.1002/anie.202009191 
(42) Zhang, H.; Min, S.; Wang, F.; Zhang, Z. "Immobilizing cobalt phthalocyanine into a porous carbonized wood membrane as a self-supported heterogenous electrode for selective and stable $\mathrm{CO} 2$ electroreduction in water," Dalton Trans 2020, 49, 15607-15611. http://dx.doi.org/10.1039/d0dt03304a (43) Liu, Y.; Leung, K. Y.; Michaud, S. E.; Soucy, T. L.; McCrory, C. C. L. "Controlled Substrate Transport To Electrocatalyst Active Sites For Enhanced Selectivity In The Carbon Dioxide Reduction Reaction," Comments Inorg. Chem. 2019, 1-28. http://dx.doi.org/10.1080/02603594.2019.1628025

(44) Canty, A. J.; Barron, P.; Healy, P. C. "1H and 199Hg NMR spectra of methylmercury(II) complexes. Effects of basicity and ortho substitution in pyridines(L) in complexes [MeHgL]NO3," J. Organomet. Chem. 1979, 179, 447-458. http://dx.doi.org/10.1016/S0022-328X(00)91861-8

(45) Canty, A. J.; Chaichit, N.; Gatehouse, B. M.; George, E. E.; Hayhurst, G. "Coordination chemistry of methylmercury(II). Synthesis, hydrogen-1 NMR, and crystallographic studies of cationic complexes of $\mathrm{MeHg}(\mathrm{II})$ with ambidentate and polydentate ligands containing pyridyl and N-substituted imidazolyl donors and involving unusual coordination geometries," Inorg. Chem. 1981, 20, 2414-2422. http://dx.doi.org/10.1021/ic50222a011

(46) Canty, A. J.; Lee, C. V. "Interaction of methylmercury(II) with N-substituted pyrazoles. .sigma.Donor ability of pyridines, imidazoles, and pyrazoles," Organometallics 1982, 1, 1063-1066. http://dx.doi.org/10.1021/om00068a012

(47) Canty, A. J.; Lee, C. V. "Relative $\sigma$ donor ability of pyridines, imidazoles, and pyrazoles," Inorg. Chim. Acta 1981, 54, L205-L206. http://dx.doi.org/10.1016/S0020-1693(00)95435-5

(48) Rabenstein, D. L. "The aqueous solution chemistry of methylmercury and its complexes," Acc. Chem. Res. 1978, 11, 100-107. http://dx.doi.org/10.1021/ar50123a004 
(49) Nyokong, T. "Equilibrium and kinetic studies of the reaction between pyridine and cobalt(II) phthalocyanine in DMSO," Polyhedron 1995, $\quad 14, \quad 2325-2329$. http://dx.doi.org/http://dx.doi.org/10.1016/0277-5387(95)00090-F

(50) Liaudet, E.; Battaglini, F.; Calvo, E. J. "Electrochemical study of sulphonated ferrocenes as redox mediators in enzyme electrodes," J. Electroanal. Chem. 1990, 293, 55-68. http://dx.doi.org/10.1016/0022$\underline{0728(90) 80052-8}$

(51) Oyama, N.; Anson, F. C. "Catalysis of electrode processes by multiply-charged metal complexes electrostatically bound to polyelectrolyte coatings on graphite electrodes, and the use of polymer-coated rotating disk electrodes in diagnosing kinetic and conduction mechanisms," Anal. Chem. 1980, 52, 11921198. http://dx.doi.org/10.1021/ac50058a009

(52) Leddy, J.; Bard, A. J. "Polymer films on electrodes: Part XII. Chronoamperometric and rotating disk electrode determination of the mechanism of mass transport through poly(vinyl ferrocene) films," $J$. Electroanal. Chem. 1983, 153, 223-242. http://dx.doi.org/10.1016/S0022-0728(83)80015-1

(53) Leddy, J.; Bard, A. J.; Maloy, J. T.; Savéant, J. M. "Kinetics of film-coated electrodes: Effect of a finite mass transfer rate of substrate across the film—solution interface at steady state," J. Electroanal. Chem. 1985, 187, 205-227. http://dx.doi.org/10.1016/0368-1874(85)85779-8

(54) Compton, R. G.; Laing, M. E.; Ledwith, A.; Abu-Abdoun, I. I. "Polymer-coated electrodes: cyclic voltammetry and chronoamperometry of non-ideal systems - the anodic oxidation of poly(4-vinyltriphenylamine) films," J. Appl. Electrochem. 1988, 18, 431-440. http://dx.doi.org/10.1007/BF01093759 (55) Shao, Y.; Gan, Z.; Epifanovsky, E.; Gilbert, A. T. B.; Wormit, M.; Kussmann, J.; Lange, A. W.; Behn, A.; Deng, J.; Feng, X.; Ghosh, D.; Goldey, M.; Horn, P. R.; Jacobson, L. D.; Kaliman, I.; Khaliullin, R. Z.; Kuś, T.; Landau, A.; Liu, J.; Proynov, E. I.; Rhee, Y. M.; Richard, R. M.; Rohrdanz, M. A.; Steele, R. P.; Sundstrom, E. J.; Woodcock, H. L.; Zimmerman, P. M.; Zuev, D.; Albrecht, B.; Alguire, E.; Austin, 
B.; Beran, G. J. O.; Bernard, Y. A.; Berquist, E.; Brandhorst, K.; Bravaya, K. B.; Brown, S. T.; Casanova, D.; Chang, C.-M.; Chen, Y.; Chien, S. H.; Closser, K. D.; Crittenden, D. L.; Diedenhofen, M.; DiStasio, R. A.; Do, H.; Dutoi, A. D.; Edgar, R. G.; Fatehi, S.; Fusti-Molnar, L.; Ghysels, A.; GolubevaZadorozhnaya, A.; Gomes, J.; Hanson-Heine, M. W. D.; Harbach, P. H. P.; Hauser, A. W.; Hohenstein, E. G.; Holden, Z. C.; Jagau, T.-C.; Ji, H.; Kaduk, B.; Khistyaev, K.; Kim, J.; Kim, J.; King, R. A.; Klunzinger, P.; Kosenkov, D.; Kowalczyk, T.; Krauter, C. M.; Lao, K. U.; Laurent, A. D.; Lawler, K. V.; Levchenko, S. V.; Lin, C. Y.; Liu, F.; Livshits, E.; Lochan, R. C.; Luenser, A.; Manohar, P.; Manzer, S. F.; Mao, S.-P.; Mardirossian, N.; Marenich, A. V.; Maurer, S. A.; Mayhall, N. J.; Neuscamman, E.; Oana, C. M.; Olivares-Amaya, R.; O’Neill, D. P.; Parkhill, J. A.; Perrine, T. M.; Peverati, R.; Prociuk, A.; Rehn, D. R.; Rosta, E.; Russ, N. J.; Sharada, S. M.; Sharma, S.; Small, D. W.; Sodt, A. "Advances in molecular quantum chemistry contained in the Q-Chem 4 program package," Mol. Phys. 2015, 113, 184-215. http://dx.doi.org/10.1080/00268976.2014.952696

(56) Chai, J.-D.; Head-Gordon, M. "Long-range corrected hybrid density functionals with damped atomatom dispersion corrections," Physical Chemistry Chemical Physics 2008, 10, 6615-6620. http://dx.doi.org/10.1039/B810189B

(57) Marenich, A. V.; Olson, R. M.; Kelly, C. P.; Cramer, C. J.; Truhlar, D. G. "Self-Consistent Reaction Field Model for Aqueous and Nonaqueous Solutions Based on Accurate Polarized Partial Charges," $J$. Chem. Theory Comput. 2007, 3, 2011-2033. http://dx.doi.org/10.1021/ct7001418

(58) Khaliullin, R. Z.; Bell, A. T.; Head-Gordon, M. "Analysis of charge transfer effects in molecular complexes based on absolutely localized molecular orbitals," J. Chem. Phys. 2008, 128, 184112. http://dx.doi.org/10.1063/1.2912041

(59) Ramdhanie, B.; Zakharov, L. N.; Rheingold, A. L.; Goldberg, D. P. "Synthesis, Structures, and Properties of a Series of Four-, Five-, and Six-Coordinate Cobalt(III) Triazacorrole Complexes: The First 
Examples of Transition Metal Corrolazines," Inorg. Chem. 2002, 41, 4105-4107. http://dx.doi.org/10.1021/ic020297x

(60) Zhang, Y.-L.; Ruan, W.-J.; Zhao, X.-J.; Wang, H.-G.; Zhu, Z.-A. "Synthesis and characterization of axial coordination cobalt(III) complexes containing chiral Salen ligands," Polyhedron 2003, 22, 15351545. http://dx.doi.org/10.1016/S0277-5387(03)00261-4

(61) Li, N.; Wang, Y.; Wu, C.; Lu, W.; Pei, K.; Chen, W. "Bioinspired catalytic generation of highvalent cobalt-oxo species by the axially coordinated CoPc on pyridine-functionalized MWCNTs for the elimination of organic contaminants," Appl. Surf. Sci. 2018, 434, 1112-1121. http://dx.doi.org/10.1016/j.apsusc.2017.11.048 
Table of Contents Image

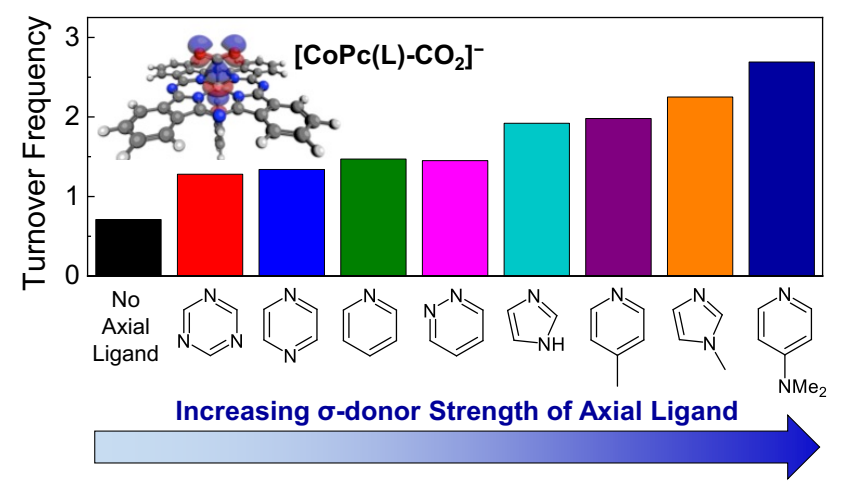

